The research program of the Center for Economic Studies (CES) produces a wide range of theoretical and empirical economic analyses that serve to improve the statistical programs of the U.S. Bureau of the Census. Many of these analyses take the form of CES research papers. The papers are intended to make the results of CES research available to economists and other interested parties in order to encourage discussion and obtain suggestions for revision before publication. The papers are unofficial and have not undergone the review accorded official Census Bureau publications. The opinions and conclusions expressed in the papers are those of the authors and do not necessarily represent those of the U.S. Bureau of the Census. Republication in whole or part must be cleared with the authors.

\title{
LINKING INVESTMENT SPIKES AND PRODUCTIVITY GROWTH:
}

\author{
U.S. FOOD MANUFACTURING INDUSTRY
}

by

Pinar Celikkol Geylani *

Duquesne University

\author{
and \\ Spiro E. Stefanou * \\ Pennsylvania State University
}

CES 08-36 October, 2008

All papers are screened to ensure that they do not disclose confidential information. Persons who wish to obtain a copy of the paper, submit comments about the paper, or obtain general information about the series should contact Sang V. Nguyen, Editor, Discussion Papers, Center for Economic Studies, Bureau of the Census, 4600 Silver Hill Road, 2K132F, Washington, DC 20233, (301-763-1882) or INTERNET address sang.v.nguyen@census.gov. 


\begin{abstract}
We investigate the relationship between productivity growth and investment spikes using Census Bureau's plant-level data set for the U.S. food manufacturing industry. We find that productivity growth increases after investment spikes suggesting an efficiency gain or plants' learning effect. However, efficiency and the learning period associated with investment spikes differ among plants' productivity quartile ranks implying the differences in the plants' investment types such as expansionary, replacement or retooling. We find evidence of both convex and non-convex types of adjustment costs where lumpy plant-level investments suggest the possibility of non-convex adjustment costs and hazard estimation results suggest the possibility of convex adjustment costs. The downward sloping hazard can be due to the unobserved heterogeneity across plants such as plants' idiosyncratic obsolescence caused by different R\&D capabilities and implies the existence of convex adjustment costs. Food plants frequently invest during their first few years of operation and high productivity plants postpone investing due to high fixed costs.

* The research in this paper was conducted while the first author was a special sworn status researcher of the U.S. Census Bureau at the Michigan Census Research Data Center. Research results and conclusions expressed herein are solely the authors', and do not necessarily reflect the views of the Census Bureau. We greatly appreciate comments on earlier draft from seminar participants at the National Taiwan University, Ohio State University, Pennsylvania State University, University of Copenhagen, University of Nebraska, and Wageningen University. This paper has been screened to ensure that no confidential data has been revealed. Support for this research from USDA/NRI (award no. 03-35400-12949) is gratefully acknowledged.
\end{abstract}




\section{LINKING INVESTMENT SPIKES AND PRODUCTIVITY GROWTH: U.S. FOOD MANUFACTURING INDUSTRY}

The role of investment in stimulating economic growth is a central issue of economic analysis. Understanding the implications and relationship of investment to productivity is an important task and it plays a crucial role for the evaluation (or initiation) of government policies, such as investment tax credits, which is based on the assumption that investment creates higher productivity.

Economic growth refers to an increase in the capacity (or potential) to produce output, not an increase in production itself, while a business cycle refers to fluctuations in actual output around a the trend of potential output. Oftentimes, discussion of economic growth typically centers on the notion of steady state. Solow (1993) notes that such characterizations in the long run ignored patterns and economic growth stimuli. One-shot productivity gains are important achievements that can lead to bursts of growth. The extent to which achievements spill over to many economic sectors (domestic and international) may lead us to experience longer periods of growth.

Conceptually, this is like jumping to a new plateau and leveling off. It is important to differentiate clearly between measurement and the policies that lift the potential trend or tilt the curve. Lifting refers to a burst of growth, while tilting refers to a change in the rate of growth. Some polices can lift the trend but not tilt it (e.g., policies seeking to increase the rate of capital - both human and physical). Other policies can tilt the curve (e.g., promoting R\&D).

This study specifically identifies investment spikes as embodying the potential to lift the plateau, models the occurrence of investment spikes which picks up the adaptation of an instantaneous technical change, and investigates the link between investment spikes and productivity at the plant level. ${ }^{1}$ Identifying the relationship between productivity and investment is a challenging task and previous research has been only partially successful. The major complication arises from the causality between investment and productivity. 
In this study, we provide micro-evidence on the question of the link between investment and productivity by analyzing confidential U.S. food manufacturing plant-level data. Focusing on the U.S. food manufacturing industry is a good empirical application to test this relationship for two reasons. First, the U.S. food processing and kindred products industry has been responsive to new technologies in processing, packaging and marketing of food product and has become increasingly high-tech over the past few decades (Morrison, 1997). The industry is a significant sector accounting for about one-sixth of the U.S. manufacturing sector's activity and it has experienced significant reorganization. Harris (2002) reports that from 1993 to the first half of 1998, meat processors accounted for 60 mergers and acquisitions, dairy processors accounted for 69 , soft drink bottlers for 53, snack food processors for 44 and poultry processors for 32. This follows over three decades of vigorous merger activity. Manufacturers attempt to increase sales, profits and market share through consolidation, industrialization, expanding exports, foreign growth and new valueadded product development (ERS, Harris, 2002). The food and kindred product industry has the sixth largest number of plants among twenty operating manufacturing industries in U.S. and produce nearly 14 percent of the total value of output in the manufacturing sector. Second, the plants in the industry present a lumpy nature of investments which makes this industry a good candidate to investigate the link between these spikes and productivity. The nature of lumpy investments in the industry provides insight into the timing of capital investments and to assess if plant productivity falls after a large investment project. With this analysis, we also are able to characterize capital adjustment patterns in the US food industry to shed lights on models that i) only assume convex costs to adjust capital, ii) only stress the presences of irreversibility and fixed adjustment costs (nonconvex capital adjustment) or iii) acknowledge the presence of both types of adjustment costs.

Recent studies in the investment and productivity literature focus on the theoretical development of investment, technology and productivity through endogenous technological 
adoption models. Cooley, Greenwood and Yorukoglu (1997) argues that new machinery embodies the latest technology, while Campbell (1998) assumes barriers to technological adoption emerge through sunk costs, which leads to newer producers having a relative advantage over existing producers in adapting to a new technology. Plant dynamics models, such as Jovanovic (1982) and Pakes and Erickson (1998), focus on plant-level heterogeneity to explain the micro-dynamics of growth. Jovanovic and Nyarko (1996) construct a learning-by-doing model where productivity after a new technological introduction can be lower than under the old technology but productivity then increases as the firm learns how to use the new technology. According to the learning-by-doing theory, we can expect that an investment spike can involve new technology installed through plant equipment. Therefore, the installation of a new technology in a plant's production process may create operational inefficiency in the early stages of a new technology, since new skills and experience need to be developed. This may lead to a drop in total factor productivity (TFP) immediately after the introduction of new technology, but in later periods, plants and firms can expect a gradual recovery. There is empirical support of this hypothesis. Sakellaris (2004) shows that lumpy investment episodes results in the costly adoption of new technologies that came with the new equipment, TFP falls after the investment spike and starts to recover slowly. He uses a descriptive and non-parametric empirical approach to investigate this process in large U.S. manufacturing plants. Hugget and Ospina (2001) analyze plant-level data from the Columbian manufacturing sector and find that productivity growth falls when a plant undertakes a large equipment purchase using the least absolute deviation as a measure of productivity change. Bessen (1999) shows that new plant productivity improves as a result of learning-by-doing and indicates that new plant adjustment is not entirely the same as mature plant adjustment after an investment spike; in particular, the large new plant lowers its workforce as it grows older. 
Another line of theoretical studies involves modeling plant dynamics that analyze the link between a range of economic variables and observable plant characteristics by looking at the implications of plant heterogeneity [Jovanovic (1982), Pakes and Erickson (1998), Cooper, Haltiwanger and Power (1999)]. Ericson and Pakes (1995) build a model to illustrate how total factor productivity (TFP) growth rates relate to investment rates. In particular, both low and high TFP growth rates suggest periods of low investment. The high mortality rate of new firms is associated with an initial learning period where most perform poorly and have low levels of investment after the initial startup costs. There is a threshold of TFP growth rates where firms decrease their investment after passing the threshold. Power (1998) empirically examines the link between investment and productivity at the plant level in U.S. manufacturing industries. The results show that no observable relationship exists between investment and productivity or productivity growth when focusing on the link between investment and labor productivity in all U.S. manufacturing industries.

Along lines of plant dynamics models, our focus is to analyze empirically the relationship between investment, productivity and plant characteristics. There are two main objectives in this paper. The first is to provide a basic description and explanation of TFP growth based on the industry average and quartile grouping of plants. The second is to investigate the link between productivity growth and large investments without imposing any causal relationship between productivity and investment. For these purposes, we first estimate reduced form regressions. The productivity growth variable is regressed on relevant plant characteristics such as plant age, investment age, plant size, and 4-digit SIC industry group. The regressions are estimated separately by industries and by quartile groups. To address cross-plant and within-plant variations in productivity growth, we estimate these regressions both with and without plant fixed effects. Then, we estimate a logit regression where the probability of having an investment spike is based on the 
time elapsed since the last plant investment, predicted productivity growth and other relevant plant variables. We test if the hazard is upward sloping to address its implications for the shape of the adjustment cost function, and if plants with higher productivity are more likely to invest.

The absence of plant-level R\&D data in this study precludes the empirical identification of the direct relationship between $\mathrm{R} \& \mathrm{D}$ and investment spikes. However, R\&D activity is associated with changes in how a firm undertakes its production activities. These changes can involve significant additions and reorganizing of production processing and capacity which involves large changes in capital stock. Initiatives to install additional capital may arise from a need to enhance productivity growth. We determine if there are strong systematic differences across plants in the food manufacturing industry using the 1972-1995 Census Bureau’s Longitudinal Research Database. We offer an in-depth analysis for the industry at the most disaggregated level and analyze its plants based on productivity quartile groups. This reveals an interesting relationship between investment spikes and productivity which is masked in studies using a general pooled-industry base.

This study presents four main findings. The first set of results presents a significant variation in productivity growth among plants in the same industry. Industry-level productivity growth presents a different picture than growth based on a quartile plant group. The second set of results finds productivity growth increases after investment spikes over time even after controlling for plant characteristics, suggesting a plant-level efficiency gain or learning effect. However, this pattern is different based on the plant's productivity quartile rank which indicates the differences in plant investment types. These plants can make expansionary (reflecting the acquisition of more capital of a technology known to the plant), or replacement (restoring depreciated capital with new capital) or retooling investments (equipment purchases reflecting technology adoption). Third, there is a decreasing probability of observing an investment spike as time passes (i.e., downward sloping hazard function). The downward sloping hazard might be as a result of the unobserved 
heterogeneity across plants such as plants' idiosyncratic obsolescence due to different R\&D capabilities, and it implies the existence of convex adjustment costs. We find evidence of both convex and non-convex types of adjustment costs in the industry. Finally, the probability of investing across plants decreases as productivity growth increases which suggests a high fixed cost which causes plants with high productivity to postpone investing.

This paper is organized as follows. The next section presents the data sources and a description of the dataset followed by an introduction of the methodology, empirical specification and results. The final section offers concluding comments.

\section{Data Sources and Lumpiness in Capital}

\section{Data Sources}

We use annual plant-level data from the Census Bureau's Longitudinal Research Database (LRD). The LRD is a panel that contains detailed plant-level information from the Annual Survey of Manufacturers (ASM) and Census of Manufacturers (CM) of all U.S. manufacturing industries. ${ }^{2}$

The balanced panel of plants in the Food and Kindred Products Industry (SIC=20) focuses mostly on the large manufacturing plants over the time period 1972-1995. The balanced nature of the data set ensures that the capital stocks are constructed using the perpetual inventory method and the lumpiness of investment is measured through time ${ }^{3}$. The balanced panel is not a random sample of plants and includes a higher proportion of large plants due to the ASM sampling strategy. Approximately one-third of ASM sample is rotated in and out of the sample every five years to minimize the reporting burden on small plants. We also analyze two of the major sub-industries in the food industry (meat and dairy products) to investigate the differences in results due to the aggregate versus disaggregate nature of the samples. Table 1 presents a general industry overview based on the panel data used in the analysis. 


\section{Lumpiness in Capital in the Food Industry}

The studies analyzing the nature of investments at plant and firm level document irreversibility (zero investment episodes mixed with periods of investment) and lumpiness (bursts of investments are surrounded by periods of low level of investment activity) (Doms and Dunne (1998), Power (1998), Cooper, Haltiwanger and Power (1999), and Nilsen and Schiantarelli (2003)). The evidence of lumpy investment can be explained by the presence of fixed costs which can be a result of the differences in capital vintages across firms and plants. The intermittent and lumpy nature of investments creates a non-smooth adjustment path for the capital stock which contrasts the standard neoclassical investment model with convex adjustment costs. Since understanding the nature of capital adjustment cost is important due to its influences on firm's investment decision, studies search for evidence about the shape of the adjustment cost instead of assuming a conventional shape. One of the most recent studies which uses structural model of capital adjustment costs finds that both convex and non-convex elements should be present in modelling adjustment costs (Cooper and Haltiwanger (2006)).

To assess the nature of investment patterns, we present main characteristics of the investment rate distribution in our data series. Throughout this study, the ratio of plant's investments on capital to its real capital stock $(\mathrm{I} / \mathrm{K})$ is used as the definition of the investment rate. Capacity-improving investment activity is measured by lumpy investments. The lumpy investments which are defined by the relative measure occurring in a given year if the plant's investment rate is greater than 2.5 times the plant's median investment rate ${ }^{4}$. The detailed study by Power (1994) describes a relative spike as being where the plant's investment is considered lumpy if it is large relative to that plant's other investments. ${ }^{5}$ 
Table 2 presents the number of spike observations and their contribution to total plant-level investment for machinery, buildings and their sum. In the food industry, only $17 \%$ of the observations present machinery investment spikes, but these account for $83 \%$ of the total

investment. A similar pattern is revealed across other industries. Even though the lumpy investment percentage is lower than the non-spike investment percentage across investment types, the percentage of total sample investment accounted for by lumpy investments are significantly higher than those that are not. This suggests that plant-level investment is quite lumpy, since a relatively small percentage of observations account for a disproportionate share of overall investments. Table 3 provides additional interesting information on investment spike concentration and documents the lumpiness of plant-level investment in the sector. It shows the number of investment spikes over a 24-year period and the percentage of the plants in each spike across three different food industries. ${ }^{6}$ In the food manufacturing industry, 97\% of the plants experience between 1 to 6 machinery investment spikes over the sample period, suggesting that, at most, only $3 \%$ never have lumpy investments. Of those plants engaged in lumpy investments between 1 to 9 times over the sample period, the median number of investment spikes is two.

\section{Linking TFP growth to Capacity-Improving Investment}

An investigation into the relationship between lumpy investment and TFP growth can draw on the results of Ericson and Pakes (1995) and Pakes and McGuire (1994) which suggest that both low and high TFP growth rates imply periods of low investment. Baumol and Wolfe (1983) achieve results similar to those found by Ericson and Pakes (1995) as they explore R\&D investment feedback effects and productivity growth rates. Productivity growth implies resource use decisions affecting the quantity of resources available for new production activities and planning, in particular. Investment spikes soon stimulate rapid productivity growth in a sector where spikes are associated 
with new technologies. But that, in turn, raises the price of investment in production capacity that increases the productivity growth rate (i.e., a retooling investment) and reduces the quantity of productive capacity demanded. In subsequent periods, productivity growth is impeded, permitting a reduction in the productive capacity price stimulating demand for capacity-improving investment yet again. While this conceptual model is highly simplified, it does pinpoint some dynamic disincentives of productive capacity investment. When productive capacity investment successfully increases productivity growth, it automatically increases its own relative costs compared to production costs leading to a reduced investment incentive. Thus, the success of capacity-improving investment serves to undermine its own demand. Unfortunately, the more impressive the past success the more strongly it tends to constrain private demand for productive capacity. Given both arguments regarding demand and supply side investment spikes and TFP growth rates, we investigate both investment spikes and TFP growth impacts. The following sections focus on the estimation of TFP growth using production function specification and investigate the relationship between TFP growth and lumpy investments for all dairy, meat and food plants.

\section{Production Function Estimation and TFP Growth Findings}

In estimating the production function, we control for simultaneity between unobservable productivity and observable input choices as a result of the profit-maximizing firms' response to positive productivity shock by expanding output, in turn, and using more inputs. Marschak and Andrews (1944) raised this problem initially and suggested that the transmitted productivity shock would be positively correlated with variable inputs and the estimated coefficients on variable inputs from least squares are likely to be biased upward (Levinsohn and Petrin (2003)). Under this condition, least squares estimates of production functions are biased which leads biased productivity estimates. Olley and Pakes (1996) address the simultaneity problem by using investment as a proxy 
to control for the part of the error correlated with inputs and thus eliminate the variation which is related with the productivity contribution. However, an investment proxy is only valid for plants reporting non-zero investment. A difficulty arises with the Olley-Pakes approach when adjustment costs are non-convex, which leads the non-responses in investment to some productivity shocks. This is specifically a concern at the plant-level sample where one can come across many zero investments. Levinsohn and Petrin (2003) address the simultaneity problem by using an intermediate input (e.g., materials, fuel, electricity) as a proxy controlling for the error associated with simultaneity. They argue that these inputs respond more smoothly to productivity shocks and are useful proxies for plant-level studies since they are generally not equal to zero. From the perspective of adjustment costs, it is less costly to adjust the intermediate input implying this input may respond more fully than investment to the entire productivity term. Consequently, the Levinsohn-Petrin approach presents a compelling remedy to the simultaneity problem in the presence of frequent zero investment observations.

We estimate a Cobb-Douglas production function using this approach with intermediate inputs to address the simultaneity problem. The estimated Cobb-Douglas production function specified in logs as

$$
y_{i t}=\beta_{0}+\beta_{k} k_{i t}+\beta_{m} m_{i t}+\beta_{l} l_{i t}+\beta_{e} e_{i t}+\beta_{t} t+\omega_{i t}+\eta_{i t}
$$

where $y_{i t}$ is the log of the output (the total value of shipments is adjusted for inventory changes) for plants $i$ and time $t$. The log of materials, labor, energy and capital are represented by $m_{i t}, l_{i t}, e_{i t}$, and $k_{i t}$, respectively. Capital is constructed using the perpetual inventory measure, which is appropriate in a balanced panel. The inventory measure of capital is accomplished by accumulating investment over time and requires continuous observations for each plant. ${ }^{7}$ The productivity impact is represented by the error term, $\omega_{i t}+\eta_{i t}$, where $\omega_{i t}$ is a transmitted error term and impacts the 
firm's decision rules, and $\eta_{i t}$ is an i.i.d. shock not known to the analyst and does not have an impact on the firm's decisions. We use the energy variable as the proxy and proceed with the estimation by rewriting equation (1) as ${ }^{8}$

$$
y_{i t}=\beta_{m} m_{i t}+\beta_{l} l_{i t}+\beta_{t} t+\phi_{i t}\left(e_{i t}, k_{i t}\right)+\eta_{i t}
$$

where

$$
\phi_{i t}\left(e_{i t}, k_{i t}\right)=\beta_{0}+\beta_{e} e_{i t}+\beta_{k} k_{i t}+\omega_{i t}\left(e_{i t}, k_{i t}\right)
$$

The demand for the intermediate input, $\boldsymbol{e}_{i t}$, is assumed to depend on the firm's state variables, $e_{i t}=e_{i t}\left(\omega_{i t}, k_{i t}\right)$. Using the Levinsohn-Petrin condition where the energy function is monotonic function with respect to the productivity shock, $\omega_{i t}$, the unobservable productivity term can be written as a function of two observed inputs, $\omega_{i t}=\left(e_{i t}, k_{i t}\right)$. The first stage estimator is linear in variable inputs and non-parametric in $\phi_{i t}$ where we can obtain consistent estimates of freely variable inputs. We employ Levinsohn-Petrin's locally weighted quadratic least squares approximation (least squares with a polynomial approximation approach) to obtain the coefficients of freely variable inputs. In the second stage, since capital and energy variables enter $\phi_{i t}($.$) twice, Levinsohn-Petrin$ propose two moment conditions to identify $\beta_{k}$ and $\beta_{e}$. To identify $\beta_{k}$, they assume that productivity shock is governed by a first-order Markov process, $\omega_{t}=E\left[\omega_{t} \mid \omega_{t-1}\right]+\xi_{t}$ where $\xi_{t}$ is an innovation to productivity that is uncorrelated with $k_{t}, E\left[\left(\xi_{t}+\eta_{t}\right) k_{t}\right]=E\left[\xi_{t} k_{t}\right]=0$ and to identify $\beta_{e}$, they assume that last period's energy choice should be uncorrelated with the innovation in productivity this period, $E\left[\left(\xi_{t}+\eta_{t}\right) e_{t-1}\right]=E\left[\xi_{t} e_{t-1}\right]=0$.

Table 4 reports coefficient estimates from least squares and Levinsohn-Petrin approaches. We find that parameter estimate on freely variable inputs from the least squares procedure exceed 
the ones from the Levinsohn-Petrin method which confirms the theoretical and empirical results discussed in their article?

We use coefficients from the production function estimation by Levinsohn and Petrin (2003) method to generate productivity growth for each plant and each year, across both meat and dairy products as well as all food manufacturing industries. Dhrymes (1991) and Bartelsman and Dhrymes (1998) present TFP growth results by deciles and their conclusions argue against characterizing the economy in terms of the representative plant or firm. These studies suggest that evaluating TFP growth patterns by quartiles can potentially reveal differing TFP growth impacts from investment spikes. Thus, after calculating a given plant's TFP growth, we rank all plants according to the magnitudes of their TFP in each year (Dhrymes, 1991). The plants are then grouped by a quartile sampling procedure ranging from I to IV (lowest to highest). This ranking allows us to classify plants exhibiting varying levels of TFP, as well as to detect if productivity is growing over time.

Table 5 provides overall and quartile group specific average TFP growth across industries. This shows that the average productivity growth over the years is $0.05 \%$ in meat products, $-1.4 \%$ in dairy products and $0.4 \%$ in all food manufacturing industries. However, classifying plants based on their productivity quartiles reveals significant variation in productivity growth. An analysis of the 3digit sub-industry level presents very different productivity growth rates even when each sub-group belongs to the same 2-digit-level aggregate industry. The meat product plants in the lowest quartile have an average growth of $-18 \%$, while the highest quartile plants are at $19 \%$. A similar pattern is seen in the dairy products sub-industry and the entire food industry with the average growth in the lowest quartile ranked plants is $-18 \%$ for dairy products and $-21 \%$ for the food industry, while the average growth in the highest quartile is $15 \%$ and $22 \%$, respectively. 
These results present several interesting observation about the industry, such that there are large differentials in the rates of productivity growth across plants within the same industry. The industry-level productivity growth presents a different picture than growth based on a quartile plant group. Most interestingly, one expects poorly performing plants to disappear in such a longer time frame in a competitive environment; however, in reality we observe low productivity plants coexist with the high productive ones. It seems high likely that differences in the quality of capital equipment, or in worker's skills, or in the development and installation of new technology and the managerial abilities of firms explain the wide variation in productivity.

\section{The Impact of Investment Spikes on Productivity Growth}

We describe an econometric model to investigate the link between investment spikes and TFP growth. For this analysis, we use the reduced form regression model as follows,

$$
Q_{i t}=\alpha+\gamma X_{i t}+\varepsilon_{i t}
$$

where the dependent variable $Q_{i t}$ is the productivity growth rate, and the independent variables $X_{i t}$ (vector) are relevant plant characteristics [e.g. plant investment age (lagged), plant size, plant age, and 4-digit SIC industry dummies]. ${ }^{10}$ The investment age variable measures the time since the plant's most recent investment spike. The range of investment age dummies is 0 to $9+$, where 0 denotes consecutive spikes, 1 represents a one-year investment spike interval, and so on, up to the nine-orgreater category. The size variable is a set of dummy variables defined as the number of employees at each plant. Plant size dummies are assigned based on their average, size-weighted employment over the sample period to account for each plant's average employment in the long term and to avoid size fluctuation through time. After finding the average size weighted employment, plant size dummy variables are created based on quartile groups. ${ }^{11}$ Table 6 reports the number of observations and plants, average size and employment based on plant size quartiles. Plant age dummy variables 
are defined in detail in the Appendix and Table 7 presents the number of plants and observations by plant age.

Our empirical estimation only focuses on machinery investment spikes, which are the type of investment that usually incorporates the latest technology. Using equation (2), we estimate a set of least-squares regressions with and without fixed effects to exploit both cross-plant and withinplant productivity variations. ${ }^{12}$ We also run these models with and without quartile groupings to assess the possible differences in the impact of investment spikes on TFP growth. Tables 8 through 10 list the estimation results from equation (2) for each industry and quartile group. Figures 1a, 1b and 1c plot the plant investment age coefficients from columns 5 through 8 in Tables $8-10 .^{13}$

A major finding from this analysis is the relationship between productivity growth and investment age contrary to the findings of Power (1998), which holds even when controlling for plant fixed effects. In general, the magnitude and significance of the investment age coefficients is robust to the presence or absence of plant fixed effects. Therefore, further discussions are based on these results, which control for the unobservable heterogeneity across plants.

The impact of investment age on productivity growth exhibits a positive trend for the meat products industry. This indicates productivity growth increases as a result of an investment spike, which may suggest an efficiency gain or learning effect. ${ }^{14}$ For example, the impact of that investment for all plants (Figure 1a) is a 4\% productivity increase one year after the investment spike, and 5\% four years after the spike. The impact of investment age on growth is the largest for the lowest quartile plants. For example, one year after the investment was executed, the investment spike impact is a productivity growth increase approaching $7 \%$, compared to a $4 \%$ increase for all plants. The pattern is an inverted U-shape, suggesting that productivity growth initially increases and then trails off. When we take a look at the same impact for the middle quartile plants, the impact graph becomes relatively flat after one year suggesting a rapid efficiency gain and/or learning effect. 
For the highest productivity plants, all the investment age coefficients are insignificant, suggesting existing production processes of these plants serve them well. This may indicate that their investment spikes are mostly an expansionary type of investment to increase their capacity. The effect of investment age on productivity growth is the highest for the least productive plants. Since they are the worst-performing plants, these plants may be introducing new technologies to boost their productivity. Thus, these investments may be a replacement or retooling type of investment. The idea that different types of investments have an effect on productivity shows up in previous research, but this has never been tested since there were no data available distinguishing investment types precisely enough [Power (1998), Huggett and Ospina (2001) and Sakellaris (2004)]. The Power (1998) study could not find a relationship between productivity and investment. This was attributed to the expansionary investment type, which need not be associated with productivity increases. An increase in productivity is expected when there is replacement or retooling type of investment. While our data does not distinguish between investment types, our results can be used to suggest different types of investments in the food manufacturing industry. We may have an expansionary type of investment for the highest ranked plants, whereas the lowest ranked plants may have a replacement or retooling type of investment in the meat products industry.

For dairy product plants in general, the impact of large investments on productivity growth is positive and is realized after four years. However, when we separate the dairy plants into quartile groups, most of the lowest quartile ranked plant estimated coefficients are insignificant. There is no significant relationship between investment age and productivity growth for these plants. However, all investment age coefficients are significant for the middle quartile group indicating that after the second year, the impact of investment age on productivity growth becomes relatively flat, leading to a relatively quick efficiency gain and/or learning effect. While this pattern is very similar to meat product plants, the investment age impact in dairy product plants is about half the rate found in 
meat plants. For the highest ranked plants, the trend is generally positive, even though some coefficients are insignificant. For these plants, the probability of an investment spike increases five years after an investment spike. In contrast to the highest ranked meat industry plants, the dairy plants seem to depend on large investments to boost their productivity. ${ }^{15}$

For the food industry, in aggregate, the most pronounced impact of investment age on productivity growth $(2.8 \%)$ occurs during the fifth year after an investment spike. Among the quartile groups, the most pronounced effect of investment age on productivity growth can be seen in the lowest ranked plants. For these plants, the investment age-productivity pattern is similar to that seen in meat product plants (almost an inverted U-shape suggesting productivity growth initially increases and then trails off); however, here the impact is much lower and starts from a lower base.

All investment age coefficients for the middle quartile ranked plants are significant. The impact of an investment spike on productivity in these plants follows a stable trend, suggesting that once an investment spike is initiated, the impact remains constant throughout the years (figure 1c). Once the plants adopt the new capacity, it either increases efficiency right away, or the technology learning period is not long, so plants see the positive effect of this technology on productivity right away.

For the highest ranked plants, the investment age productivity growth impact declines after the large investment is made. Large spikes generally require significant plant-level learning, and as a result, the investment spike's impact appears in later periods, and the productivity benefits from investment are realized more slowly. The learning period is longer for these highest-ranked plants compared to some plants observed in the meat and dairy products industries. We see this pattern for the highest ranked plants in figure 1c; i.e., productivity falls up to investment age 3, and a positive impact of investment age on productivity occurs during investment ages 3 and 4. 


\section{The Impact of Productivity Growth on Investment Spikes}

Studies addressing the cost of capital adjustments (Cooper, Haltiwanger and Power(1999), Cooper and Haltiwanger (2006), Nilsen and Schintarelli (2003)) postulate that increasing investment hazard (positive duration dependence) is an indication of non-convex forms of adjustment costs. Our first objective for this section is to investigate the shape of the capital adjustment cost by estimating the hazard function to see if the probability of an investment spike increases as the time since the last investment spike increases (i.e., increasing investment hazard). The second objective is to determine if an increase in productivity raises the probability of an investment spike. To achieve these objectives, we specify a logit regression and assess the change in the probability of an investment spike based on the productivity. ${ }^{16}$ We characterize the probability of having an investment spike as a function of investment age, productivity growth and other determinants of investment spikes (some plant control variables) as follows,

$$
\operatorname{Pr}\left(I_{i, t}=1\right)=\Lambda\left(\beta_{0}+\beta_{1} X_{i, t}+\beta_{2} T F P_{i, t-\tau}\right)
$$

where $I_{i, t}=1$ if a plant has an investment spike in that year and $I_{i, t}=0$ otherwise. $X_{i, t}$ is a vector set of relevant plant-level characteristics such as dummies for a plant's lagged investment age, size, age, and 4-digit SIC industry. The last argument is a productivity growth variable $T F P_{i, t-\tau}$ lagged $\tau$ periods. When deciding the number of periods to lag TFP, various options were explored, such as the lagged value of predicted TFP (first, second and third lags) and moving averages [2-year MA, 3year MA centered on (t-2), and 4-year MA]. 
Tables 11-13 list the coefficients, marginal effects, and robust standard errors from logit regressions in equation (3) across industries and quartile groups. Figures 2a-2c plot the investment age dummy variable coefficients from these tables. ${ }^{17}$

For all meat industry plants, as well as the middle quartile plants, the investment age dummy coefficient estimates are all positive and significant (Table 11), except for the "4+ years" collapsed investment age group. ${ }^{18}$ Plants with a negative estimated investment age coefficient are most likely to have an investment spike at age $9+$ (the omitted category). Figure 2 a shows that the probability of having an investment spike decreases with respect to investment age in both middle quartile and "all plants" categories. This probability decreases sharply after the current and two consecutive investments, and then declines gradually for the other investment ages. Investment age coefficients for the middle quartile ranked plants are significant. Our results differ from the upward sloping hazard function where the probability of an investment spike increases as the time since the last investment spike increases due to depreciation and technical change. The plants of this industry are early investors since we observe high frequency investment in early investment ages. These plants appear to use the new technology investments (lumpy investments) until it depreciates out.

One possible explanation of a downward sloping hazard function can be the existence of unobserved heterogeneity across plants, for example, Power (1994) finds that idiosyncratic obsolescence of plants due to different R\&D capabilities may lead to downward sloping hazard. ${ }^{19}$ Another implication of downward sloping hazard is, when a spike is not occurring, the plant is likely to still be making small investments. This supports the presence of both convex and non-convex components of adjustment costs in the industry. If there is a convex component of adjustment costs, we can observe small investments episodes even in the presence of fixed components. Nilsen and Schiantarelli (2003) find that small investment rates are fairly frequent and quantitatively important in the Norwegian plant-level data. Most recently, the presence of a mixed form of 
adjustment costs (convex and non-convex) is explored in a structural model of adjustment by Cooper and Haltiwanger (2006) and their results suggest that a model incorporating both types of adjustment costs fit the data best.

Test results to address if plants with higher productivity are more likely to invest show that the probability of investing across plants decreases as productivity growth increases. This suggests that there is a high fixed cost for the lumpy investments in the industry. The first lag of productivity coefficient is negative and significant, which implies that the fixed cost of investment causes plants with high productivity to postpone investing.

In the dairy products industry, investment age dummy coefficient estimates are all positive and significant for both middle quartile ranked and all plants (Table 12), with the exception of an insignificant " $6+$ investment age". Figure $2 \mathrm{~b}$ shows that the probability of an investment spike decreases with investment age in both middle quartile ranked and "all plants" categories. After the current and two consecutive investments, this probability decreases sharply, and then declines gradually for the later investment ages. In the "all plants" category, this pattern does fluctuate and is not as smooth as that for the middle quartile plants.

Analysis of the dairy products sub-industry shows similarities to the meat products industry with the presentation of a downward sloping hazard function. Similarly, logit results show that the probability of investing across plants decreases as productivity growth increases, since the fixed cost of lumpy investment encourages plants to delay their investments. For the middle quartile and "all plants" categories, the productivity coefficient is negative and significant at $1 \%$ and $10 \%$, respectively (Table 12).

For all food manufacturing plants, enough observations exist to include the lowest and highest quartile plants in our investigation. For the lowest and highest ranked plants, the investment age dummy's coefficient estimates are all positive and significant for the first four years. Similarly, 
for the middle-ranked and "all plants" categories, these estimates are positive and significant for the first five years (Table 13).

Figure $2 \mathrm{c}$ shows that the probability of having an investment spike decreases with investment age for all ranked groups, as well as pooled plants. The general trend indicates that the likelihood of having an investment spike decreases sharply after the current investment is made and for two consecutive investments, and then declines gradually for the subsequent ages. However, there are some fluctuations in the likelihood of investment spikes for the highest ranked plants. Except for the middle quartile-ranked plants, the likelihood of having an investment spike increases during investment ages 1 and 2. This is still early during the investment age periods so, in general, plants in the food industry have a high frequency of investments in early years as compared to later years. In line with Power's findings in some industries, this may indicate that plants in the food industry may have a rapid obsolescence rate; therefore, they invest more frequently than plants with a slower obsolescence rate.

Not surprisingly, as with the other sub-industries, the logit results suggest that the fixed cost of investment leads to a declining probability of investing across plants as productivity growth increases. This fixed cost of lumpy investments causes plants with high productivity to delay their investments since the productivity coefficients from Table 13 are negative and significant at 5\% for the smallest quartile, middle quartile, and "all plants" categories, and significant at $1 \%$ for the highest quartile plants.

\section{Concluding Comments}

The main goal of this study is to examine the widely assumed relationship between productivity and investment spikes by using a rich plant-level data set for the food manufacturing industry and two important sub-industries (meat and dairy products industries) from 1972 to 1995 . We investigate the 
link between productivity growth and large investments without imposing any causal relationship between productivity and investment. To achieve this, we first estimated reduced form regressions where productivity growth variable is regressed on plant age, investment age, plant size, and 4-digit SIC industry group. The regressions are estimated separately by industry and by quartile groups of plants. Then, we estimate a logit regression where the probability of having an investment spike based on the time elapsed since the last investment episode at plants, productivity growth and other relevant plant variables. We test for if the hazard is upward sloping and to test for if plants with higher productivity are more likely to invest.

This study offers several key results. First, there is a significant variation in productivity growth among plants in the same industry. Productivity growth at the industry level is different from growth measurement based on a quartile group of plants. Second, we find strong evidence of a link between productivity growth and investment age in existing plants. Our results show that productivity growth increases after investment spikes over time and then trails off, even after controlling for plant fixed effects in most of the plants, suggesting a plant-level efficiency gain or learning effect. However, we find that there are differences in productivity growth and investment spike patterns when we categorize plants based on productivity quartile ranks. Our results imply that there are differences in the investment types plants make in a particular industry, such as expansionary, replacement or retooling investments.

We also find that efficiency and the learning period associated with investment spikes differs among quartile groups. Middle-ranked plants in the meat industry see the positive effects right away once the new technology is adopted. This suggests that these plants experience an immediate increase in efficiency, or the new technology learning period is relatively short. However, for the food industry's highest productivity quartile plants, productivity growth declines after an investment spike, which suggests that the learning period is longer and productivity benefits from these 
investments are realized more slowly. By focusing on existing plants, this study reveals that lumpy investments not only occur at new plants as most of the existing studies emphasize but also at surviving plants. This result coincides with the Huggett and Ospina (2001) investigation of Columbian plants.

Third, there is a decreasing probability of an investment spike as the time since the last spike increases, which may be attributed to idiosyncratic plant obsolescence due to different R\&D capabilities and may imply the existence of convex adjustment costs in the industry. It is also possible that not all investment spikes are supporting growth directly. For example, investment spikes can be associated with improvements in food safety and quality assurance processes that are mandated by regulatory acts and new product development that is intended to maintain competitive positions in markets. Our results show that plants in the food industry are early investors since we observe a high frequency of such investments in the early years. Our findings support the presence of both types of adjustment costs in the industry such a way that the evidence of lumpy investments suggests the possibility of non-convex adjustment costs, and the hazard estimation results suggest the possibility of convex adjustment costs.

Finally, the probability of investing across plants decreases as productivity growth increases. This suggests that high fixed costs associated with lumpy investments cause plants with high productivity to postpone investing. The natural next step would be a structural estimation model in a dynamic context that would link plant-level investment spikes and productivity. Even though our data does not differentiate between the different types of investments, our results imply that plants in the industry could have different types of investment (e.g. expansionary, replacement or retooling). Another direction for future research is to analyze datasets to show the distinction among different types of investment and their effects on productivity growth. 


\section{Appendix: Variable Construction}

Total V alue of Shipments: This study uses the total value of shipment as the output measure. The gross shipment is defined as the total value of shipment plus inventory change deflated by the 4-digit Bartelsman-Gray's shipment deflator (Bartelsman and Gray, 1996). In this method, which is different from the value added approach, material and energy inputs are included as a separate variable in the production function estimation. ${ }^{20}$ The real total value of shipments (real value of sales as output) of a plant is found as

$$
R E T V S=\frac{T V S+[(W I E-W I B)+(F I E-F I B)]}{P I S H I P}
$$

The variables are defined as follows: TVS is the total value of shipments; WIE (WIB) refers to work in process inventories end of year (beginning of year); FIE (FIB) refers to finished products inventories end of year (beginning of year); PISHIP is the 4-digit Bartelsman-Gray's shipment deflator.

Material Variable: The LRD contains information on the cost of materials as $C M=C P+C R+C F+$ $E E+C W$ where $C P$ is cost of materials, parts, etc., $C R$ is cost of resale, $C F$ is cost of fuel, $E E$ is cost of purchased electricity and $C W$ is cost of contract work. Since material and energy variables are considered as separate inputs in this study, $C P+C R+C W$ is considered a material variable which is deflated with the 4-digit Bartelsman-Gray's materials deflator.

Energy Variable: The LRD contains information on the cost of fuels and electricity usage. CF is the cost of fuel (expenditures on fuel for heating, electricity generation, and production), and EE is the cost of purchased electricity (does not include electricity produced by the plant for its own use). In 
this study, the energy variable is taken to be $C F+E E$ and deflated by the 4-digit Bartelsman-Gray's energy deflator.

Labor Variable: The labor variable holds production worker hours as in the Olley and Pakes (1996) study, and is defined as

$$
L H=\frac{S W+L C}{\frac{W W}{P H}},
$$

where total compensation of labor is divided by the average production worker wage rate. In this equation, $S W$ is total salaries and wages (the sum of production workers wages and non-production worker salaries); $L C$ is total supplementary cost; $W W$ is the plant's total production worker wages; PH is the total production work hours.

Capital Stock Variable: The real capital stock variable is constructed using the perpetual inventory method for the dataset. The LRD contains information on buildings and machinery. This way each stock can be calculated separately and then added together to find the plant's total capital stock. The perpetual inventory method requires finding the capital value during the panel time period based on 1972 as a benchmark year. To find the real capital stock, investment is calculated over the 1972-1995 time period. The nominal gross investment is deflated using 4-digit SIC investment deflators (Bartelsman-Gray's investment deflator). The capital stock benchmark value for each plant in 1972 is initialized by multiplying the machinery and equipment book value by the ratio of real to book value of the machinery and equipment for the 2-digit industry in which the plant operates in 1972..$^{21}$ The perpetual inventory method, $K_{i t}=I_{i t}+\left(1-\delta_{i}\right) K_{i,(t-1)}$, is then used to obtain the panel's real capital stock. In this equation, $K_{i t}$ is the real stock at time $t, I_{i t}$ is the real investment 
occurring during year $t$, and $\delta_{i}$ is the rate of replacement. Depreciation is $5 \%$ and $15 \%$ for buildings and machinery, respectively.

Plant Size Measurement: The size variable is a set of dummy variables defined as the number of employees at each plant. Using the method in Power (1998), we find size classes based on their average. Size-weighted employment over the entire sample period is defined as

$$
S=\frac{1}{\text { Mean } T E} \sum_{i=1}^{23} T E^{2}
$$

where $T E_{i}=$ total employment in year $i$ and Mean $T E=\frac{\sum_{i=1}^{23} T E_{i}}{n}$.

Plant Age Measurement: Using a dummy variable, the age of a plant is determined by comparing the age when the plant first appears in the Census $(1963,1967$ or 1972) with the first year of our sample (1972). Using this approach to capture the plant age differences, only an approximate age variable can be assigned by comparing the plants in existence earlier (1963 or 1967) with the plants existed in 1972. For example, since LRD does not contain ASM panels prior to 1969, if a plant was not included in 1963 Census but was included in 1967, the plant could be anywhere from five to nine years old in 1972. Therefore, exact age cannot be constructed for the plants already existing in 1972. Then, the plants' age dummies are assigned as follows:

Age0: Plants that appear for the first time in 1972 Census. Age0 plants are considered the youngest in our sample period, are considered to be new and are assumed to be 23 years old in 1995 . Age1: Plants listed in 1967 are considered to be approximately 5 years old in 1972 and 28 years old in 1995. 
Age2: These plants are the oldest, as they were listed in the 1995 Census. They are considered to be approximately 9 years old in 1972 and 32 years old in 1995.

Investment Age Variable: After identifying investment spikes for each plant over the years, the investment age variable is constructed by measuring the time since the plant's most recent investment spike. Based on our panel from 1972 to 1995, we constructed the investment age dummies. The range of investment age dummies is $0-9+$ where 0 denotes consecutive spikes, investment age 1 represents a one year interval between investment spikes, and so on up to the nineor-greater category. The time since the plant's most recent investment spike can also be viewed as an indicator of the plant's capital vintage. 


\section{References}

Baumol, W. J. and E. N. Wolfe. 1983. "Feedback from Productivity Growth to R\&D," The Scandinavian Journal of Economics, 85(2):147-157.

Bartelsman, E., and W. Gray. 1996. NBER Manufacturing Productivity Database. Technical Working Paper No. 205, National Bureau of Economic Research, Harvard University.

Bessen, E. J.,1999. "New Plants and Natural Experiments in Economics Adjustment: Adjustment Costs, Learning-by-doing and Lumpy Investment,” Working Paper, Boston University.

Caballero, R., E. Engle and J. C. Haltiwanger. 1995. "Plant-Level Adjustment and Aggregate Investment Dynamics," Brookings Papers on Economic Activity, 2: 1-39.

Campbell, J. 1998. "Entry, Exit, Embodied Technology, and Business Cycles," Review of Economic Dynamics, 1(2):371-408.

Cooley, T., J. Greenwood and M. Yorukoglu. 1997. “The Replacement Problem,” Journal of Monetary Economics, 40(3):457-500.

Cooper, R. and J. C. Haltiwanger. 2006. "On the Nature of Capital Adjustment Costs," Review of Economic Studies, 73:611-633.

Cooper, R., J. C. Haltiwanger and L. Power. 1999. "Machine Replacement and the Business Cycle: Lumps and Bumps," The American Economic Review, 89(4): 921-946.

Dhrymes, P. J. 1991. "The Structure of Production Technology: Productivity and Aggregation Effects," Discussion Paper CES 91-5, Center for Economic Studies, U.S. Bureau of Census, Washington, DC.

Doms, M. and T. Dunne. 1998. "Capital Adjustment Patterns in Manufacturing Plants," Review of Economic Dynamics, 1: 409-429.

Dwyer, W. D. 1996. "Productivity Races II: The Issue of Capital Measurement," Discussion Paper CES-WP-97-3, Center for Economic Studies, U.S. Bureau of Census, Washington, DC.

Ericson R. and A. Pakes. 1995. "Markov Perfect Industry Dynamics: A Framework for Empirical Work," Review of Economic Studies, 62(1): 53-82.

Harris, M. J. 2002. "Food Manufacturing," U.S. Food Marketing System, AER-811, Economic Research Service, USDA: 3-9.

Hsiao, C. 1989. Analysis of Panel Data, New York: Cambridge University Press.

Huggett, M. and S. Ospina. 2001. "Does Productivity Growth Fall after the Adoption of New Technology?” Journal of Monetary Economics, 48 (1):173-195.

Jovanovic, B. 1982. "Selection and Evolution of Industry," Econometrica, 50(3):649-670. 
Jovanovic, B. and Y. Nyarko. 1996. "Learning-by-Doing and the Choice of Technology," Econometrica, 64(6):1299-1310.

Levinsohn, J. and A. Petrin. 2003. "Estimating Production Functions Using Inputs to Control for Unobservables," Review of Economic Studies, 70(2, 243): 317-342.

Morrison, C. J. 1997. "Structural Change, Capital Investment and Productivity in the Food Processing Industry," American Journal of Agricultural Economics 79(1):110-125.

Nilsen, O.A. and F. Schiantarelli. 2003. "Zeros and Lumps in Investment: Empirical Evidence on Irreversibility and Nonconvexities," The Review of Economics and Statistics, 85(4):1021-1037.

Olley, G.S. and A. Pakes. 1996. "The Dynamics of Productivity in the Telecommunication Equipment Industry,” Econometrica, 64(6):1263-1297.

Pakes, A. and R. Ericson. 1998. "Empirical Implications of Alternative Models of Firm Dynamics," Journal of Economic Theory, 79(1):1-46.

Pakes, A and P. McGuire. 1994. "Computing Markov-Perfect Nash Equilibria: Numerical Implications of a Dynamic Differentiated Product Model," RAND Journal of Economics, 25(4):555-589.

Power, L. 1994. Causes and Consequences of Investment Spikes in U.S. Manufacturing Plants. Ph.D. Dissertation, University of Maryland.

Power, L. 1998. "The Missing Link: Technology, Investment, and Productivity," Review of Economics and Statistics, 80(2): 300-313.

Sakellaris, P. 2004. "Patterns of Plant Adjustment," Journal of Monetary Economics, 51(2): 425-450.

Solow, R. M. 1993. "Policies for Economic Growth," Tinbergen Lectures on Economic Policy, in Knoester, A. and Wellink, A. H. E. M., eds. Amsterdam: North-Holland: 127-140. 
Table 1. Number of Observations and Plants by Sub-industries and All Food Industry Plants Together

\begin{tabular}{|l|l|l|}
\hline Three Digit Sub-Industries* & $\begin{array}{l}\text { Meat } \\
\text { Products } \\
\text { (SIC=201) }\end{array}$ & $\begin{array}{l}\text { Dairy } \\
\text { Products } \\
\text { (SIC=202) }\end{array}$ \\
\hline Number of Plants & 204 & 163 \\
\hline Number of Observations & 4722 & 3775 \\
\hline Percent of Total Plants & 16 & 13 \\
\hline Machinery Investments of the Total Industry's Machinery Investments (\%) & 10.4 & 6.1 \\
\hline Building Investments of the Total Industry's Buildings Investments (\%) & 15.6 & 7.2 \\
\hline $\begin{array}{l}\text { Combined Machinery and Building Investments of the Total Industry's } \\
\text { Combined Machinery and Building Investments (\%) }\end{array}$ & 11.4 & 6.3 \\
\hline Material Expenditure of the Total Industry's Material Expenditures (\%) & 28.6 & 11.2 \\
\hline Energy Expenditure of the Total Industry's Energy Expenditures (\%) & 13.3 & 7.3 \\
\hline Labor Expenditure of the Total Industry's Labor Expenditures (\%) & 25.2 & 6.1 \\
\hline Total Value of Shipments of the Industry's Total Value of Shipments (\%) & 21.1 & 9.3 \\
\hline Average Employment of the Total Industry's Employment (\%) & 19 & 5.5 \\
\hline
\end{tabular}

* Number of plants in all Food Industries (SIC = 20) 1233 and with 29592 observations 
Table 2. Investment Spike Characteristics in Industries across Investment Types

\begin{tabular}{|l|l|l|l|l|l|l|}
\hline Industries & \multicolumn{2}{|l|}{ Meat Products Industry } & \multicolumn{2}{l|}{ Dairy Products Industry } & \multicolumn{2}{l|}{ Food Manufacturing Industry } \\
\hline $\begin{array}{l}\text { Investment } \\
\text { Rate* }\end{array}$ & $\begin{array}{l}\text { \% of Obs. in } \\
\text { Data set } \\
\text { which are } \\
\text { spikes and } \\
\text { non-spikes }\end{array}$ & $\begin{array}{l}\text { \% of Total } \\
\text { Sample } \\
\text { Investment } \\
\text { Accounted } \\
\text { for by spikes } \\
\text { and non- } \\
\text { spikes** }\end{array}$ & $\begin{array}{l}\text { Data set } \\
\text { which are } \\
\text { spikes and } \\
\text { non-spikes }\end{array}$ & $\begin{array}{l}\text { Sample } \\
\text { Investment } \\
\text { Accounted } \\
\text { for by spikes } \\
\text { and non- } \\
\text { spikes }\end{array}$ & $\begin{array}{l}\text { Data set in } \\
\text { which are } \\
\text { spikes and } \\
\text { non-spikes }\end{array}$ & $\begin{array}{l}\text { Sample } \\
\text { Investment } \\
\text { Accounted } \\
\text { for by spikes } \\
\text { and non- } \\
\text { spikes }\end{array}$ \\
\hline Machinery & 17 spike & 84 spike & 20 spike & 88 spike & $\begin{array}{l}17 \text { spike } \\
83 \text { non-spike }\end{array}$ & $\begin{array}{l}83 \text { spike } \\
17 \text { non-spike }\end{array}$ \\
\hline Buildings & 35 spike & 97 spike & $\begin{array}{l}37 \text { spike } \\
63 \text { non-spike }\end{array}$ & $\begin{array}{l}99 \text { spike } \\
1 \text { non-spike }\end{array}$ & $\begin{array}{l}35 \text { spike } \\
65 \text { non-spike }\end{array}$ & $\begin{array}{l}97 \text { non-spike } \\
3 \text { non-spike }\end{array}$ \\
\hline $\begin{array}{l}\text { Combined } \\
\text { Machinery } \\
\text { and } \\
\text { Buildings }\end{array}$ & 20 spike & 87 spike & 21 spike & $\begin{array}{l}88 \text { spike } \\
12 \text { non-spike }\end{array}$ & $\begin{array}{l}19 \text { spike } \\
81 \text { non-spike }\end{array}$ & $\begin{array}{l}84 \text { spike } \\
16 \text { non-spike }\end{array}$ \\
\hline
\end{tabular}

$*$ Relative spike defined as investment rate that exceeds [(2.5*median investment rate)].

** Percent of total sample investment accounted for by spikes is found by the ratio of investment spikes to total investment. 
Table 3. Number of Investment Spikes and the Percentage of Plants in each Spike across Industries

\begin{tabular}{|l|l|l|l|l|l|l|l|l|l|}
\hline & \multicolumn{3}{|l|}{ Meat Products Industry } & \multicolumn{3}{l}{ Dairy Products Industry } & \multicolumn{3}{l|}{ Food Manufacturing Industry } \\
\hline & Mach. & Build. & $\begin{array}{l}\text { Mach.\& } \\
\text { Build. }\end{array}$ & Mach. & Build. & $\begin{array}{l}\text { Mach.\& } \\
\text { Build. }\end{array}$ & Mach. & Build. & $\begin{array}{l}\text { Mach.\& } \\
\text { Build. }\end{array}$ \\
\hline Spikes & $\begin{array}{l}\text { \% of } \\
\text { Plants }\end{array}$ & $\begin{array}{l}\text { \% of } \\
\text { Plants }\end{array}$ & $\begin{array}{l}\text { \% of } \\
\text { Plants }\end{array}$ & $\begin{array}{l}\text { \% of } \\
\text { Plants }\end{array}$ & $\begin{array}{l}\text { \% of } \\
\text { Plants }\end{array}$ & $\begin{array}{l}\text { \% of } \\
\text { Plants }\end{array}$ & $\begin{array}{l}\text { \% of } \\
\text { Plants }\end{array}$ & $\begin{array}{l}\text { \% of } \\
\text { Plants }\end{array}$ & $\begin{array}{l}\text { \% of } \\
\text { Plants }\end{array}$ \\
\hline 1 & 3.92 & 1.47 & 3.43 & 1.227 & 0.613 & 0.613 & 0.406 & 0.162 & 0.162 \\
\hline 2 & 4.9 & 0.98 & 3.92 & 4.908 & 0.613 & 6.135 & 7.299 & 1.217 & 5.677 \\
\hline 3 & 22.06 & 2.45 & 12.26 & 14.11 & 3.067 & 7.362 & 24.412 & 2.758 & 15.896 \\
\hline 4 & 32.84 & 4.9 & 25.98 & 28.834 & 3.067 & 20.245 & 30.495 & 4.785 & 28.467 \\
\hline 5 & 23.04 & 4.9 & 24.02 & 28.221 & 4.908 & 25.153 & 24.006 & 8.921 & 24.655 \\
\hline 6 & 8.33 & 12.26 & 16.67 & 17.791 & 12.883 & 27.607 & 10.138 & 9.895 & 15.491 \\
\hline 7 & & 11.77 & 8.33 & & 10.429 & 11.043 & & 11.273 & 7.461 \\
\hline 8 & & 12.75 & & & 15.951 & & & 14.355 & \\
\hline 9 & & 18.14 & & & 12.883 & & & 12.247 & \\
\hline 10 & & 10.78 & & & 9.202 & & & 11.192 & \\
\hline 11 & & 7.35 & & & 9.816 & & & 7.38 & \\
\hline 12 & & & & & & & & 5.515 & \\
\hline
\end{tabular}


Table 4. Coefficient Estimates from Least Squares and Levinsohn and Petrin (LP) Approaches across Industries

\begin{tabular}{|l|l|l|l|l|l|l|}
\hline & \multicolumn{2}{|l|}{$\begin{array}{l}\text { Meat Products } \\
\text { Industry }\end{array}$} & \multicolumn{2}{l|}{$\begin{array}{l}\text { Dairy Products } \\
\text { Industry }\end{array}$} & \multicolumn{2}{l|}{ All Food Industry } \\
\hline & OLS & LP & OLS & LP & OLS & LP \\
\hline Capital & 0.0231 & 0.0700 & 0.0455 & 0.0800 & 0.0735 & 0.0100 \\
& $(0.0061)$ & $(0.0324)$ & $(0.0112)$ & $(0.0321)$ & $(0.0050)$ & $(0.0050)$ \\
\hline Labor & 0.0741 & 0.0654 & 0.1286 & 0.1123 & 0.1840 & 0.1784 \\
& $(0.0205)$ & $(0.0197)$ & $(0.0158)$ & $(0.0133)$ & $(0.0080)$ & $(0.0081)$ \\
\hline Material & 0.7621 & 0.7563 & 0.7687 & 0.7649 & 0.6532 & 0.6441 \\
& $(0.0208)$ & $(0.0228)$ & $(0.0230)$ & $(0.0219)$ & $(0.0097)$ & $(0.0091)$ \\
\hline Energy & 0.1259 & 0.1100 & 0.0687 & 0.0900 & 0.0705 & 0.1000 \\
& $(0.0217)$ & $(0.1268)$ & $(0.0225)$ & $(0.1046)$ & $(0.0089)$ & $(0.0173)$ \\
\hline
\end{tabular}

Note: Standard errors are in parentheses. The Wald tests of constant returns to scale from Levinsohn and Petrin (2003) method are as follows; for meat product industry Chi-squared $=0.02(\mathrm{p}=0.8949)$, for dairy products industry Chi-squared $=0.27(\mathrm{p}=0.6024)$, and for all food industry Chi-squared $=18.71(\mathrm{p}=0.0000)$. These results show that meat and dairy product industries have CRTS and all food industry have DRTS.

Table 5. TFP Growth across Industries and Quartile Groups

\begin{tabular}{|l|l|l|l|}
\hline Quartile & $\begin{array}{l}\text { Mean TFP Growth } \\
\text { in Meat }\end{array}$ & $\begin{array}{l}\text { Mean TFP Growth } \\
\text { in Dairy }\end{array}$ & $\begin{array}{l}\text { Mean TFP Growth } \\
\text { in All Food }\end{array}$ \\
\hline Lowest (I) & -0.1826 & -0.1836 & -0.2056 \\
\hline Lower Middle (II) & -0.0291 & -0.0383 & -0.0272 \\
\hline Upper Middle (III) & 0.0228 & 0.0094 & 0.0345 \\
\hline Highest (IV) & 0.1905 & 0.1547 & 0.2149 \\
\hline ALL & 0.0005 & -0.0142 & 0.0042 \\
\hline
\end{tabular}


Table 6. Number of Observations and Plants, Organized by Plant Size Quartile, in the Entire Food Industry

\begin{tabular}{|l|l|l|l|l|l|}
\hline $\begin{array}{l}\text { Average } \\
\text { Size } \\
\text { Quartiles }\end{array}$ & $\begin{array}{l}\text { Number of } \\
\text { Observations }\end{array}$ & $\begin{array}{l}\text { Number of } \\
\text { Plants }\end{array}$ & $\begin{array}{l}\text { Average Size } \\
\text { by } \\
\text { Employment } \\
\text { Index } \\
\text { (Size variable) }\end{array}$ & $\begin{array}{l}\text { Average Size } \\
\text { by } \\
\text { Employment } \\
\text { Index as \% of } \\
\text { Total Average } \\
\text { Employment } \\
\text { Index }\end{array}$ & $\begin{array}{l}\text { Average } \\
\text { Employment }\end{array}$ \\
\hline $\begin{array}{l}0-25 \% \\
\text { Quartile } \\
\text { Group (A) }\end{array}$ & 7392 & 308 & 1754.75 & $4.4 \%$ & 68.08 \\
\hline $\begin{array}{l}25-50 \% \\
\text { Quartile } \\
\text { Group (B) }\end{array}$ & 7392 & 308 & 5468.52 & $13.6 \%$ & 212.39 \\
\hline $\begin{array}{l}50-75 \% \\
\text { Quartile } \\
\text { Group (C) }\end{array}$ & 7416 & 309 & 9806.55 & $24.3 \%$ & 379.68 \\
\hline $\begin{array}{l}75-100 \% \\
\text { Quartile } \\
\text { Group (D) }\end{array}$ & 7392 & 308 & 23255.97 & $57.7 \%$ & 885.18 \\
\hline
\end{tabular}


Table 7. Number of Observations and Plants, Organized by Plant Ages, in the Entire Food Industry

\begin{tabular}{|c|c|c|c|c|}
\hline Plant Age* & $\begin{array}{l}\text { Number of } \\
\text { Observations }\end{array}$ & $\begin{array}{l}\text { Number of } \\
\text { Plants }\end{array}$ & $\begin{array}{l}\text { Fraction in the } \\
\text { Data set }\end{array}$ & $\begin{array}{l}\text { Average } \\
\text { Employment }\end{array}$ \\
\hline $\begin{array}{l}\text { Age 0 } \\
\text { (Newborn Plants } \\
\text { in1972) }\end{array}$ & 4224 & 176 & $14 \%$ & 291.53 \\
\hline $\begin{array}{l}\text { Age } 1 \\
\text { (5-year-old plants in } \\
1972 \text { ) }\end{array}$ & 2808 & 117 & $9.5 \%$ & 360.10 \\
\hline $\begin{array}{l}\text { Age } 2 \\
(9 \text {-year-old plants in } \\
1972)\end{array}$ & 22464 & 936 & $76.2 \%$ & 407.57 \\
\hline
\end{tabular}

*The first year of panel data, 1972, is taken as a benchmark to find plant age. 
Table 8. Regression Results of Investment Spike Effects on TFP Growth in the Meat Products Industry

\begin{tabular}{|c|c|c|c|c|c|c|c|c|}
\hline & \multicolumn{4}{|c|}{ Productivity Growth Regression without plant fixed effects } & \multicolumn{4}{|c|}{ Productivity Growth Regression with plant fixed effects } \\
\hline & $\begin{array}{l}\text { Smallest } \\
\text { Quartile Ranked } \\
\text { Plants } \\
(1) \\
\end{array}$ & $\begin{array}{l}\text { Medium Quartile } \\
\text { Ranked Plants } \\
\text { (2) }\end{array}$ & $\begin{array}{l}\text { The Highest Quartile } \\
\text { Ranked Plants } \\
\text { (3) }\end{array}$ & $\begin{array}{l}\text { All Plants } \\
\text { Together } \\
\text { (4) } \\
\end{array}$ & $\begin{array}{l}\text { Smallest } \\
\text { Quartile Ranked } \\
\text { Plants } \\
\text { (5) } \\
\end{array}$ & $\begin{array}{l}\text { Medium Quartile } \\
\text { Ranked Plants } \\
\text { (6) }\end{array}$ & $\begin{array}{l}\text { Highest Quartile } \\
\text { Ranked Plants } \\
(7) \\
\end{array}$ & $\begin{array}{l}\text { All Plants } \\
\text { Together } \\
(8) \\
\end{array}$ \\
\hline Investment Age & & & & & & & & \\
\hline 0 years old & $\begin{array}{l}0.02626 \\
(0.02462)\end{array}$ & $\begin{array}{l}0.00496 \\
(0.00455)\end{array}$ & $\begin{array}{l}-0.00089 \\
(0.02316)\end{array}$ & $\begin{array}{l}0.01174 \\
(0.01014)\end{array}$ & $\begin{array}{l}0.05158^{*} \\
(0.02745)\end{array}$ & $\begin{array}{l}0.01025^{* *} \\
(0.00479)\end{array}$ & $\begin{array}{l}-0.00550 \\
(0.03307)\end{array}$ & $\begin{array}{l}0.02059 \\
(0.01332)\end{array}$ \\
\hline 1 year old & $\begin{array}{l}0.04479 * \\
(0.02382)\end{array}$ & $\begin{array}{l}0.03339 * * * \\
(0.00425)\end{array}$ & $\begin{array}{l}-0.04203^{* *} \\
(0.02125)\end{array}$ & $\begin{array}{l}0.02924 * * * \\
(0.00986)\end{array}$ & $\begin{array}{l}0.06646^{* * * *} \\
(0.02569)\end{array}$ & $\begin{array}{l}0.03818^{* * *} \\
(0.00441)\end{array}$ & $\begin{array}{l}-0.04497 \\
(0.02909)\end{array}$ & $\begin{array}{l}0.03760^{* * *} \\
(0.01213)\end{array}$ \\
\hline 2 years old & $\begin{array}{l}0.06794 * * * \\
(0.01850)\end{array}$ & $\begin{array}{l}0.03137 * * * \\
(0.00412)\end{array}$ & $\begin{array}{l}-0.01628 \\
(0.02492)\end{array}$ & $\begin{array}{l}0.03046^{* * *} \\
(0.00875)\end{array}$ & $\begin{array}{l}0.08482 * * * \\
(0.02464)\end{array}$ & $\begin{array}{l}0.03796 * * * \\
(0.00439)\end{array}$ & $\begin{array}{l}-0.03625 \\
(0.03039)\end{array}$ & $\begin{array}{l}0.03875^{* * *} \\
0.01215)\end{array}$ \\
\hline 3 years old & $\begin{array}{l}0.07504^{* * *} \\
(0.02225)\end{array}$ & $\begin{array}{l}0.02787 * * * \\
(0.00360)\end{array}$ & $\begin{array}{l}-0.03373 \\
(0.02537)\end{array}$ & $\begin{array}{l}0.02991 * * * \\
(0.00856)\end{array}$ & $\begin{array}{l}0.08720^{* * *} \\
(0.02643)\end{array}$ & $\begin{array}{l}0.03498^{* * *} \\
(0.00478)\end{array}$ & $\begin{array}{l}-0.03593 \\
(0.03215)\end{array}$ & $\begin{array}{l}0.03851 \text { *** } \\
(0.01309)\end{array}$ \\
\hline 4 years old & $\begin{array}{l}0.07850^{* * *} \\
(0.02149)\end{array}$ & $\begin{array}{l}0.03804 * * * \\
(0.00392)\end{array}$ & $\begin{array}{l}-0.03542 \\
(0.02832)\end{array}$ & $\begin{array}{l}0.04188^{* * *} \\
(0.01045)\end{array}$ & $\begin{array}{l}0.07667 * * * \\
(0.02773)\end{array}$ & $\begin{array}{l}0.04305^{* * *} \\
(0.00519)\end{array}$ & $\begin{array}{l}-0.05286 \\
(0.03338)\end{array}$ & $\begin{array}{l}0.04895^{* * *} \\
(0.01395)\end{array}$ \\
\hline 5 years old & $\begin{array}{l}0.08456^{* * *} \\
(0.02108)\end{array}$ & $\begin{array}{l}0.03734 * * * \\
(0.00408)\end{array}$ & $\begin{array}{l}-0.02396 \\
(0.02568)\end{array}$ & $\begin{array}{l}0.04583^{* * *} \\
(0.01006)\end{array}$ & $\begin{array}{l}0.11152^{* * *} \\
(0.03058)\end{array}$ & $\begin{array}{l}0.04343^{* * *} \\
(0.00536)\end{array}$ & $\begin{array}{l}-0.03775 \\
(0.03469)\end{array}$ & $\begin{array}{l}0.05320^{* * *} \\
(0.01462)\end{array}$ \\
\hline 6 years old & $\begin{array}{l}0.04071 \\
(0.02868)\end{array}$ & $\begin{array}{l}0.03037 * * * \\
(0.00399)\end{array}$ & $\begin{array}{l}-0.02916 \\
(0.02409)\end{array}$ & $\begin{array}{l}0.02966^{* *} \\
(0.01266)\end{array}$ & $\begin{array}{l}0.05918^{*} \\
(0.03068)\end{array}$ & $\begin{array}{l}0.03405^{* * *} \\
(0.00564)\end{array}$ & $\begin{array}{l}-0.03258 \\
(0.03656)\end{array}$ & $\begin{array}{l}0.03536 * * \\
(0.01526)\end{array}$ \\
\hline 7 years old & $\begin{array}{l}0.07214 * * * \\
(0.02163)\end{array}$ & $\begin{array}{l}0.02947 * * * \\
(0.00394)\end{array}$ & $\begin{array}{l}0.00635 \\
(0.04035)\end{array}$ & $\begin{array}{l}0.03077^{* *} \\
(0.01324)\end{array}$ & $\begin{array}{l}0.07992^{* *} \\
(0.03167)\end{array}$ & $\begin{array}{l}0.03379^{* * *} \\
(0.00547)\end{array}$ & $\begin{array}{l}-0.01217 \\
(0.04105)\end{array}$ & $\begin{array}{l}0.03628^{* *} \\
(0.01559)\end{array}$ \\
\hline 8 years old & $\begin{array}{l}0.06331 * * * \\
(0.01937)\end{array}$ & $\begin{array}{l}0.02941 * * * \\
(0.00425)\end{array}$ & $\begin{array}{l}-0.01344 \\
(0.02870)\end{array}$ & $\begin{array}{l}0.03843 * * * \\
(0.01244)\end{array}$ & $\begin{array}{l}0.06296^{* *} \\
(0.03203)\end{array}$ & $\begin{array}{l}0.03471^{* * * *} \\
(0.00578)\end{array}$ & $\begin{array}{l}-0.03456 \\
(0.03814)\end{array}$ & $\begin{array}{l}0.04371 * * * \\
(0.01577)\end{array}$ \\
\hline $\begin{array}{l}\text { Plant Age } \\
\text { Age0 }\end{array}$ & $\begin{array}{l}0.00009 \\
(0.01294)\end{array}$ & $\begin{array}{l}0.00057 \\
(0.00209)\end{array}$ & $\begin{array}{l}0.00422 \\
(0.01680)\end{array}$ & $\begin{array}{l}-0.00094 \\
(0.00382)\end{array}$ & $\mathrm{X}$ & $\mathrm{X}$ & X & $\mathrm{X}$ \\
\hline Age1 & $\begin{array}{l}-0.01258 \\
(0.02194)\end{array}$ & $\begin{array}{l}-0.00067 \\
(0.00369)\end{array}$ & $\begin{array}{l}0.04624 \\
(0.04239)\end{array}$ & $\begin{array}{l}0.00887 \\
(0.00894)\end{array}$ & $\mathrm{X}$ & $\mathrm{X}$ & $\mathrm{X}$ & $\mathrm{X}$ \\
\hline Plant Size & 0.02971 & 0.00128 & & & & & & \\
\hline Medium & $(0.01931)$ & $\begin{array}{l}0.00128 \\
(0.00282)\end{array}$ & $\begin{array}{l}-0.07170^{* * *} \\
(0.02575)\end{array}$ & $\begin{array}{l}-0.00337 \\
(0.00513)\end{array}$ & $\begin{array}{l}-0.09445 \\
(0.24651)\end{array}$ & $\begin{array}{l}0.02441 \\
(0.02513)\end{array}$ & $\mathrm{X}$ & $\begin{array}{l}0.03945 \\
(0.08746)\end{array}$ \\
\hline Medium-Large & $\begin{array}{l}0.01219 \\
(0.02195)\end{array}$ & $\begin{array}{l}0.00064 \\
(0.00265)\end{array}$ & $\begin{array}{l}-0.02521 \\
(0.03064)\end{array}$ & $\begin{array}{l}0.00591 \\
(0.00617)\end{array}$ & $\begin{array}{l}-0.00481 \\
(0.28306)\end{array}$ & $\begin{array}{l}0.05298 \\
(0.03648)\end{array}$ & $\begin{array}{l}0.26828 \\
(0.22166)\end{array}$ & $\begin{array}{l}0.10542 \\
(0.11406)\end{array}$ \\
\hline Largest & $\begin{array}{l}0.01745 \\
(0.01963)\end{array}$ & $\begin{array}{l}0.00583^{* *} \\
(0.00256)\end{array}$ & $\begin{array}{l}-0.03371 \\
(0.02947)\end{array}$ & $\begin{array}{l}0.01032^{*} \\
(0.00541)\end{array}$ & $\begin{array}{l}0.10174 \\
(0.31533)\end{array}$ & $\mathrm{X}$ & $\begin{array}{l}0.27279 \\
(0.34076)\end{array}$ & $\begin{array}{l}0.10313 \\
(0.15239)\end{array}$ \\
\hline $\mathrm{N}$ & 1113 & 2255 & 1116 & 4484 & 1113 & 2255 & 1116 & 4484 \\
\hline
\end{tabular}

Note: Coefficients from fixed effect and without fixed effect regressions are reported. Robust standard errors are in parenthesis. Each regression includes 4-digit SIC industry controls. The omitted categories are as follows: investment age 9+, the oldest plant age category, the smallest size category, SIC=2017 (Poultry and Egg Processing). ***, **, and $*$ represent 1, 5, and 10\% significance, respectively. X represents variables that are dropped from the fixed effect regression since these regressions measure within-plant productivity variation (here, the plant age and some size categories are dropped from the fixed effect regressions). 
Table 9. Regression Results of Investment Spike Effects on TFP Growth in the Dairy Products Industry

\begin{tabular}{|c|c|c|c|c|c|c|c|c|}
\hline & \multicolumn{4}{|c|}{ Productivity Growth Regression without plant fixed effects } & \multicolumn{4}{|c|}{ Productivity Growth Regression with plant fixed effects } \\
\hline & $\begin{array}{l}\text { Smallest Quartile } \\
\text { Ranked Plants } \\
\text { (1) }\end{array}$ & $\begin{array}{l}\text { Medium Quartile } \\
\text { Ranked Plants } \\
\text { (2) }\end{array}$ & $\begin{array}{l}\text { Highest Quartile } \\
\text { Ranked Plants } \\
\text { (3) }\end{array}$ & $\begin{array}{l}\text { All Plants } \\
\text { Together } \\
(4)\end{array}$ & $\begin{array}{l}\text { Smallest Quartile } \\
\text { Ranked Plants } \\
\text { (5) }\end{array}$ & $\begin{array}{l}\text { Medium Quartile } \\
\text { Ranked Plants } \\
\text { (6) }\end{array}$ & $\begin{array}{l}\text { Highest Quartile } \\
\text { Ranked Plants } \\
\text { (7) }\end{array}$ & $\begin{array}{l}\text { All Plants } \\
\text { Together } \\
(8)\end{array}$ \\
\hline Investment Age & & & & & & & & \\
\hline 0 years old & $\begin{array}{l}-0.01804 \\
(0.02132)\end{array}$ & $\begin{array}{l}0.00834^{* *} \\
(0.00381)\end{array}$ & $\begin{array}{l}0.00905 \\
(0.01636)\end{array}$ & $\begin{array}{l}0.00411 \\
(0.00964)\end{array}$ & $\begin{array}{l}-0.01264 \\
(0.02317)\end{array}$ & $\begin{array}{l}0.01055^{* *} \\
(0.00416)\end{array}$ & $\begin{array}{l}0.02956 \\
(0.02411)\end{array}$ & $\begin{array}{l}0.00714 \\
(0.01147)\end{array}$ \\
\hline 1 year old & $\begin{array}{l}0.01939 \\
(0.02020)\end{array}$ & $\begin{array}{l}0.01703^{* * *} \\
(0.00295)\end{array}$ & $\begin{array}{l}0.02197 \\
(0.01802)\end{array}$ & $\begin{array}{l}0.02603^{* * *} \\
(0.00963)\end{array}$ & $\begin{array}{l}0.03234 \\
(0.02201)\end{array}$ & $\begin{array}{l}0.01944 * * * \\
(0.00384)\end{array}$ & $0.03717^{*}$ & $0.02942^{* * *}$ \\
\hline 2 years old & $\begin{array}{l}0.03315^{* *} \\
(0.01617)\end{array}$ & $\begin{array}{l}0.02361 * * * \\
(0.00305)\end{array}$ & $\begin{array}{l}-0.00120 \\
(0.01523)\end{array}$ & $\begin{array}{l}0.03095^{* * *} \\
(0.00793)\end{array}$ & $\begin{array}{l}0.02349 \\
(0.02285)\end{array}$ & $\begin{array}{l}0.02636^{* * *} \\
(0.00387)\end{array}$ & $\begin{array}{l}0.00132 \\
(0.02149)\end{array}$ & $\begin{array}{l}0.03378^{* * *} \\
(0.01079)\end{array}$ \\
\hline 3 years old & $\begin{array}{l}-0.00026 \\
(0.02312)\end{array}$ & $\begin{array}{l}0.01992^{* * *} \\
(0.00335)\end{array}$ & $\begin{array}{l}-0.01237 \\
(0.01449)\end{array}$ & $\begin{array}{l}0.00414 \\
(0.00959)\end{array}$ & $\begin{array}{l}-0.00232 \\
(0.02315)\end{array}$ & $\begin{array}{l}0.02088^{* * *} * \\
(0.00410)\end{array}$ & $\begin{array}{l}0.02305 \\
(0.02513)\end{array}$ & $\begin{array}{l}0.00820 \\
(0.01153)\end{array}$ \\
\hline 4 years old & $\begin{array}{l}0.05711 * * * \\
(0.01547)\end{array}$ & $\begin{array}{l}0.02277^{* * *} \\
(0.00327)\end{array}$ & $\begin{array}{l}0.05227 * * \\
(0.02597)\end{array}$ & $\begin{array}{l}0.03809^{* * *} \\
(0.01073)\end{array}$ & $\begin{array}{l}0.06285^{* * *} \\
(0.02305)\end{array}$ & $\begin{array}{l}0.02487^{* * *} * \\
(0.00449)\end{array}$ & $\begin{array}{l}0.08291^{* * *} * \\
(0.02569)\end{array}$ & $\begin{array}{l}0.04115^{\text {*** }} \\
(0.01215)\end{array}$ \\
\hline 5 years old & $\begin{array}{l}0.04754 * * \\
(0.02066)\end{array}$ & $\begin{array}{l}0.02323^{* * *} \\
(0.00357)\end{array}$ & $\begin{array}{l}0.02748 \\
(0.03648)\end{array}$ & $\begin{array}{l}0.03770^{* * *} \\
(0.01192)\end{array}$ & $\begin{array}{l}0.04815^{*} \\
(0.02697)\end{array}$ & $\begin{array}{l}0.02295^{* * *} \\
(0.00446)\end{array}$ & $\begin{array}{l}0.04102 \\
(0.02657)\end{array}$ & $\begin{array}{l}0.04001 \text { *** } \\
(0.01272)\end{array}$ \\
\hline 6 years old & $\begin{array}{l}-0.02944 \\
(0.03665)\end{array}$ & $\begin{array}{l}0.0256^{* * * *} \\
(0.00328)\end{array}$ & $\begin{array}{l}0.03915 \\
(0.03189)\end{array}$ & $\begin{array}{c}-0.00344 \\
(0.01666)\end{array}$ & $\begin{array}{l}-0.02046 \\
(0.02478)\end{array}$ & $\begin{array}{l}0.02675^{* * *} \\
(0.00484)\end{array}$ & $\begin{array}{l}0.07287^{* *} \\
(0.03241)\end{array}$ & $\begin{array}{l}-0.00138 \\
(0.01353)\end{array}$ \\
\hline 7 years old & $\begin{array}{l}0.00451 \\
(0.02647)\end{array}$ & $\begin{array}{l}0.02206^{* * *} \\
(0.00429)\end{array}$ & $\begin{array}{l}0.06244^{*} \\
(0.03436)\end{array}$ & $\begin{array}{l}0.04217^{* * *} \\
(0.01506)\end{array}$ & $\begin{array}{l}-0.00479 \\
(0.03009)\end{array}$ & $\begin{array}{l}0.02159^{* * *} \\
(0.00505)\end{array}$ & $\begin{array}{l}0.06401 * * \\
(0.02793)\end{array}$ & $\begin{array}{l}0.04406^{* * *} \\
(0.01415)\end{array}$ \\
\hline 8 years old & $\begin{array}{l}-0.01761 \\
(0.03249)\end{array}$ & $\begin{array}{l}0.02525^{* * *} \\
(0.00405)\end{array}$ & $\begin{array}{l}0.07477 * \\
(0.04141)\end{array}$ & $\begin{array}{l}0.02194 \\
(0.01947)\end{array}$ & $\begin{array}{l}-0.01736 \\
(0.02843)\end{array}$ & $\begin{array}{l}0.02598^{* * *} \\
(0.00544)\end{array}$ & $\begin{array}{l}0.08875^{* * * *} \\
(0.03172)\end{array}$ & $\begin{array}{l}0.02301 \\
(0.01482)\end{array}$ \\
\hline Plant Age & & & & & & & & \\
\hline Age0 & $\begin{array}{l}0.00043 \\
(0.01721)\end{array}$ & $\begin{array}{l}0.00109 \\
(0.00238)\end{array}$ & $\begin{array}{l}0.00508 \\
(0.02055)\end{array}$ & $\begin{array}{l}-0.00176 \\
(0.00292)\end{array}$ & $\mathrm{X}$ & $\mathrm{X}$ & $\mathrm{X}$ & $\mathrm{X}$ \\
\hline Age1 & $\begin{array}{l}-0.00701 \\
(0.01524)\end{array}$ & $\begin{array}{l}-0.00290 \\
(0.00288)\end{array}$ & $\begin{array}{l}0.00563 \\
(0.03057)\end{array}$ & $\begin{array}{l}-0.00262 \\
(0.00464)\end{array}$ & $\mathrm{x}$ & $\mathrm{x}$ & $\mathrm{x}$ & $\mathrm{X}$ \\
\hline Plant Size & & & & & & & & \\
\hline Medium & $\begin{array}{l}0.00433 \\
(0.01606)\end{array}$ & $\begin{array}{l}0.00004 \\
(0.00240)\end{array}$ & $\begin{array}{c}-0.00349 \\
(0.01947)\end{array}$ & $\begin{array}{l}-0.00389 \\
(0.00308)\end{array}$ & $\begin{array}{l}-0.07025 \\
(0.19845)\end{array}$ & $\begin{array}{l}-0.13372 * * * \\
(0.04607)\end{array}$ & $\begin{array}{l}-0.13830 \\
(0.11643)\end{array}$ & $\begin{array}{l}-0.10798 \\
(0.08327)\end{array}$ \\
\hline Medium-Large & $\begin{array}{l}-0.00477 \\
(0.01742)\end{array}$ & $\begin{array}{l}0.00237 \\
(0.00262)\end{array}$ & $\begin{array}{l}-0.02238 \\
(0.01872)\end{array}$ & $\begin{array}{c}-0.00587 * \\
(0.00355)\end{array}$ & $\begin{array}{l}-0.03628 \\
(0.30315)\end{array}$ & $\begin{array}{l}-0.11672^{* *} \\
(0.04960)\end{array}$ & $\begin{array}{l}-0.21734 \\
(0.23927)\end{array}$ & $\begin{array}{c}-0.08844 \\
(0.10637)\end{array}$ \\
\hline Largest & $\begin{array}{l}-0.00489 \\
(0.01786)\end{array}$ & $\begin{array}{l}0.00389 \\
(0.00239)\end{array}$ & $\begin{array}{l}0.00742 \\
(0.02065)\end{array}$ & $\begin{array}{l}0.00203 \\
(0.00341)\end{array}$ & $\begin{array}{l}0.10755 \\
(0.33194)\end{array}$ & $\begin{array}{l}-0.04808 \\
(0.05382)\end{array}$ & $\begin{array}{l}-0.01447 \\
(0.27555)\end{array}$ & $\begin{array}{c}-0.02672 \\
(0.12148)\end{array}$ \\
\hline $\mathrm{N}$ & 887 & 1804 & 890 & 3581 & 887 & 1804 & 890 & 3581 \\
\hline
\end{tabular}

Note: Coefficients from fixed effect and without fixed effect regressions are reported. Robust standard errors are in parenthesis. Each regression includes 4-digit SIC industry controls. The omitted categories are as follows: investment age $9+$, the oldest plant age category, the smallest size category, SIC $=2021$ (Creamery Butter). ***, $* *$, and $*$ represent 1,5 , and $10 \%$ significance, respectively. X represents variables that are dropped from the fixed effect regression since these regressions measure within-plant productivity variation (here, the plant age categories are dropped from the fixed effect regressions). 
Table 10. Regression Results of Investment Spike Effects on TFP Growth in the Food Manufacturing Industry

\begin{tabular}{|c|c|c|c|c|c|c|c|c|}
\hline & \multicolumn{4}{|c|}{ Productivity Growth Regression without plant fixed effects } & \multicolumn{4}{|c|}{ Productivity Growth Regression with plant fixed effects } \\
\hline & $\begin{array}{l}\text { Smallest Quartile } \\
\text { Ranked Plants } \\
(1) \\
\end{array}$ & $\begin{array}{l}\text { Medium Quartile } \\
\text { Ranked Plants } \\
\text { (2) } \\
\end{array}$ & $\begin{array}{l}\text { Highest Quartile } \\
\text { Ranked Plants } \\
\text { (3) } \\
\end{array}$ & $\begin{array}{l}\text { All Plants } \\
\text { Together } \\
(4) \\
\end{array}$ & $\begin{array}{l}\text { Smallest Quartile } \\
\text { Ranked Plants } \\
\text { (5) } \\
\end{array}$ & $\begin{array}{l}\text { Medium Quartile } \\
\text { Ranked Plants } \\
(6) \\
\end{array}$ & $\begin{array}{l}\text { Highest Quartile } \\
\text { Ranked Plants } \\
\text { (7) } \\
\end{array}$ & $\begin{array}{l}\text { All Plants } \\
\text { Together } \\
(8) \\
\end{array}$ \\
\hline Investment Age & & & & & & & & \\
\hline 0 years old & $\begin{array}{l}0.00259 \\
(0.00875)\end{array}$ & $\begin{array}{l}0.00464 * * * \\
(0.00145)\end{array}$ & $\begin{array}{l}0.02094 * * \\
(0.00964)\end{array}$ & $\begin{array}{l}0.00922 * * \\
(0.00427)\end{array}$ & $\begin{array}{l}0.01055 \\
(0.01017)\end{array}$ & $\begin{array}{l}0.00545^{* * *} \\
(0.00137)\end{array}$ & $\begin{array}{l}0.02499 * * \\
(0.01132)\end{array}$ & $\begin{array}{l}0.01078^{* *} \\
(0.00519)\end{array}$ \\
\hline 1 year old & $\begin{array}{l}0.00715 \\
(0.00819)\end{array}$ & $\begin{array}{l}0.00576^{* * *} \\
(0.00128)\end{array}$ & $\begin{array}{l}-0.00727 \\
(0.01286)\end{array}$ & $\begin{array}{l}0.00821 * \\
(0.00489)\end{array}$ & $\begin{array}{l}0.02097 * * \\
(0.00972)\end{array}$ & $\begin{array}{l}0.00710^{* * *} \\
(0.00128)\end{array}$ & $\begin{array}{l}-0.01726 * \\
(0.01054)\end{array}$ & $\begin{array}{l}0.00962 * * \\
(0.00489)\end{array}$ \\
\hline 2 years old & $\begin{array}{l}0.02226^{* * *} \\
(0.00855)\end{array}$ & $\begin{array}{l}0.00743^{* * *} \\
(0.00118)\end{array}$ & $\begin{array}{c}-0.01502^{*} \\
(0.00784)\end{array}$ & $\begin{array}{l}0.00714^{*} \\
(0.00389)\end{array}$ & $\begin{array}{l}0.03863^{* * *} \\
(0.00977)\end{array}$ & $\begin{array}{l}0.00836^{* * *} \\
(0.00128)\end{array}$ & $\begin{array}{l}-0.02405^{* *} \\
(0.01060)\end{array}$ & $\begin{array}{l}0.00836^{*} \\
(0.00492)\end{array}$ \\
\hline 3 years old & $\begin{array}{l}0.00178 \\
(0.01251)\end{array}$ & $\begin{array}{l}0.00777 * * * \\
(0.00122)\end{array}$ & $\begin{array}{l}-0.02901 * * * \\
(0.00786)\end{array}$ & $\begin{array}{l}0.00068 \\
(0.00459)\end{array}$ & $\begin{array}{l}0.01527 \\
(0.01056)\end{array}$ & $\begin{array}{l}0.00866^{* * *} \\
(0.00136)\end{array}$ & $\begin{array}{l}-0.03208^{* * *} \\
(0.01142)\end{array}$ & $\begin{array}{l}0.00223 \\
(0.00526)\end{array}$ \\
\hline 4 years old & $\begin{array}{l}0.02451 * * \\
(0.00974)\end{array}$ & $\begin{array}{l}0.01111^{* * *} \\
(0.00125)\end{array}$ & $\begin{array}{l}-0.01379 \\
(0.00879)\end{array}$ & $\begin{array}{l}0.00447 \\
(0.00459)\end{array}$ & $\begin{array}{l}0.03014^{* * *} \\
(0.01047)\end{array}$ & $\begin{array}{l}0.01255^{* * *} \\
(0.00147)\end{array}$ & $\begin{array}{l}-0.02218^{*} \\
(0.01207)\end{array}$ & $\begin{array}{l}0.00575 \\
(0.00554)\end{array}$ \\
\hline 5 years old & $\begin{array}{l}0.04655^{* * *} \\
(0.00827)\end{array}$ & $\begin{array}{l}0.01042^{* * *} \\
(0.00134)\end{array}$ & $\begin{array}{l}0.00239 \\
(0.01283)\end{array}$ & $\begin{array}{l}0.02683^{* * *} \\
(0.00513)\end{array}$ & $\begin{array}{l}0.0648^{* * *} \\
(0.01159)\end{array}$ & $\begin{array}{l}0.01115^{* * *} \\
(0.00153)\end{array}$ & $\begin{array}{l}0.00384 \\
(0.01193)\end{array}$ & $\begin{array}{l}0.02812^{* * *} \\
(0.00576)\end{array}$ \\
\hline 6 years old & $\begin{array}{l}0.01216 \\
(0.01473)\end{array}$ & $\begin{array}{l}0.00754 * * * \\
(0.00147)\end{array}$ & $\begin{array}{l}-0.01638^{*} \\
(0.01003)\end{array}$ & $\begin{array}{l}0.00496 \\
(0.00585)\end{array}$ & $\begin{array}{l}0.02542^{* *} \\
(0.01184)\end{array}$ & $\begin{array}{l}0.00823^{* * *} \\
(0.00158)\end{array}$ & $\begin{array}{l}-0.01627 \\
(0.01288)\end{array}$ & $\begin{array}{l}0.00632 \\
(0.00601)\end{array}$ \\
\hline 7 years old & $\begin{array}{l}0.02251^{* *} \\
(0.01085)\end{array}$ & $\begin{array}{l}0.00882^{* * *} \\
(0.00154)\end{array}$ & $\begin{array}{l}0.00559 \\
(0.01172)\end{array}$ & $\begin{array}{l}0.01475^{* *} \\
(0.00595)\end{array}$ & $\begin{array}{l}0.02623^{* *} \\
(0.01207)\end{array}$ & $\begin{array}{l}0.00959 * * * \\
(0.00166)\end{array}$ & $\begin{array}{l}0.00471 \\
(0.01301)\end{array}$ & $\begin{array}{l}0.01583^{* *} \\
(0.00621)\end{array}$ \\
\hline 8 years old & $\begin{array}{l}0.01374 \\
(0.01203)\end{array}$ & $\begin{array}{l}0.00941^{* * *} \\
(0.00158)\end{array}$ & $\begin{array}{l}0.01181 \\
(0.01167)\end{array}$ & $\begin{array}{l}0.01192^{*} \\
(0.00614)\end{array}$ & $\begin{array}{l}0.01012 \\
(0.01268)\end{array}$ & $\begin{array}{l}0.00953^{* * *} \\
(0.00167)\end{array}$ & $\begin{array}{l}0.00427 \\
(0.01402)\end{array}$ & $\begin{array}{l}0.01256^{* *} \\
(0.00642)\end{array}$ \\
\hline $\begin{array}{l}\text { Plant Age } \\
\text { Age0 }\end{array}$ & $\begin{array}{l}-0.00905 \\
(0.00843)\end{array}$ & $\begin{array}{l}-0.00141 \\
(0.00097)\end{array}$ & $\begin{array}{l}0.01345 \\
(0.00932)\end{array}$ & $\begin{array}{l}0.00203 \\
(0.00173)\end{array}$ & $\mathrm{X}$ & $\mathrm{X}$ & $\mathrm{X}$ & X \\
\hline Age1 & $\begin{array}{l}-0.02956^{* *} \\
(0.01157)\end{array}$ & $\begin{array}{l}-0.00112 \\
(0.00112)\end{array}$ & $\begin{array}{l}0.02228^{*} \\
(0.01294)\end{array}$ & $\begin{array}{l}-0.00321 \\
(0.00228)\end{array}$ & $\mathrm{X}$ & $\mathrm{X}$ & $\mathrm{X}$ & $\mathrm{X}$ \\
\hline $\begin{array}{l}\text { Plant Size } \\
\text { Medium }\end{array}$ & $\begin{array}{l}0.00586 \\
(0.00876)\end{array}$ & $\begin{array}{l}0.00216^{*} \\
(0.00121)\end{array}$ & $\begin{array}{l}-0.02406^{* *} \\
(0.01008)\end{array}$ & $\begin{array}{l}-0.00225 \\
(0.00162)\end{array}$ & $\mathrm{X}$ & $\mathrm{X}$ & $\mathrm{X}$ & $\mathrm{X}$ \\
\hline Medium-Large & $\begin{array}{l}0.00679 \\
(0.01066)\end{array}$ & $\begin{array}{l}0.00087 \\
(0.00123)\end{array}$ & $\begin{array}{l}-0.03127^{* * *} \\
(0.01198)\end{array}$ & $\begin{array}{l}-0.00386 * * \\
(0.00182)\end{array}$ & $\mathrm{X}$ & $\mathrm{X}$ & $\mathrm{X}$ & $\mathrm{X}$ \\
\hline Largest & $\begin{array}{l}0.01823^{*} \\
(0.01088) \\
\end{array}$ & $\begin{array}{l}0.00413^{* * *} \\
(0.00133) \\
\end{array}$ & $\begin{array}{l}-0.03464 * * * \\
(0.01273)\end{array}$ & $\begin{array}{l}0.00199 \\
(0.00202)\end{array}$ & $\mathrm{X}$ & $\mathrm{X}$ & $\mathrm{X}$ & $\mathrm{X}$ \\
\hline $\mathrm{N}$ & 7040 & 14106 & 7044 & 28190 & 7040 & 14106 & 7044 & 28190 \\
\hline
\end{tabular}

Note: Coefficients from fixed effect and without fixed effect regressions are reported. Robust standard errors are in parenthesis. Each regression includes 4-digit SIC industry controls. The omitted categories are as follows: investment age $9+$, the oldest plant age category, the smallest size category, SIC $=2011$ (Meat Packing). $* * *, * *$, and $*$ represent 1,5 , and $10 \%$ significance, respectively. X represents variables that are dropped from the fixed effect regression since these regressions measure within-plant productivity variation. 
Table 11. Logit Results: The Probability of Having an Investment Spike in the Meat Products Industry.

\begin{tabular}{|c|c|c|c|c|}
\hline & \multicolumn{2}{|c|}{$\begin{array}{l}\text { Medium Quartile Ranked Plants } \\
\text { (1) }\end{array}$} & \multicolumn{2}{|c|}{$\begin{array}{l}\text { All Plants Together } \\
\text { (2) }\end{array}$} \\
\hline & Coefficients & Marginal Effect & Coefficients & Marginal Effect \\
\hline \multicolumn{5}{|l|}{ Investment Age } \\
\hline \multirow[t]{2}{*}{0 years old } & $3.13145^{* * *}$ & $0.45788^{* * *}$ & $2.56954 * * *$ & $0.40849 * * *$ \\
\hline & $(0.25907)$ & $(0.05283)$ & $(0.15763)$ & $(0.03399)$ \\
\hline \multirow[t]{2}{*}{1 year old } & $1.62768^{* * * *}$ & $0.15104^{* * *}$ & $1.32679 * * *$ & $0.14937 * * *$ \\
\hline & $(0.28705)$ & $(0.03902)$ & $(0.17038)$ & $(0.02599)$ \\
\hline \multirow[t]{2}{*}{2 years old } & $1.55627 * * *$ & $0.14036^{* * *}$ & $1.09005^{* * *}$ & $0.11389 * * *$ \\
\hline & $(0.29035)$ & $(0.03797)$ & $(0.17971)$ & $(0.02467)$ \\
\hline \multirow[t]{2}{*}{3 years old } & $1.26645^{* * *}$ & $0.10492^{* * *}$ & $0.70623^{* * *}$ & $0.06555^{* * *}$ \\
\hline & $(0.32776)$ & $(0.03857)$ & $(0.21144)$ & $(0.02418)$ \\
\hline \multirow[t]{2}{*}{4 years old and more } & -0.10142 & -0.00502 & -0.11052 & -0.00779 \\
\hline & $(0.34735)$ & $(0.01678)$ & $(0.18881)$ & $(0.01298)$ \\
\hline \multicolumn{5}{|l|}{ Plant Age } \\
\hline \multirow[t]{2}{*}{ Age 0} & -0.03697 & -0.00186 & 0.11412 & 0.00849 \\
\hline & $(0.32544)$ & $(0.01617)$ & $(0.20453)$ & $(0.01568)$ \\
\hline \multirow[t]{2}{*}{ Age2 } & -0.05752 & -0.00295 & 0.04011 & 0.00288 \\
\hline & $(0.28156)$ & $(0.0146)$ & $(0.17709)$ & $(0.01262)$ \\
\hline \multicolumn{5}{|l|}{ Plant Size } \\
\hline \multirow[t]{2}{*}{ Medium } & -0.10103 & -0.00501 & -0.05214 & -0.00373 \\
\hline & $(0.24234)$ & $(0.01174)$ & $(0.15269)$ & $(0.01079)$ \\
\hline \multirow[t]{2}{*}{ Medium-Large } & -0.28799 & -0.01375 & -0.10066 & -0.00712 \\
\hline & $(0.24773)$ & $(0.01113)$ & $(0.15403)$ & $(0.01067)$ \\
\hline \multirow[t]{2}{*}{ The Largest } & -0.22068 & -0.01068 & $-0.31314^{*}$ & $-0.02122^{*}$ \\
\hline & $(0.24838)$ & $(0.01147)$ & $(0.16266)$ & $(0.01032)$ \\
\hline \multirow[t]{2}{*}{ Productivity } & $-1.32531 * *$ & $-0.06724 * *$ & $-0.80977 * * *$ & $-0.05849 * * *$ \\
\hline & $(0.53132)$ & $(0.0271)$ & $(0.25924)$ & $(0.01868)$ \\
\hline $\mathrm{N}$ & 2152 & & 4285 & \\
\hline
\end{tabular}

Note: Coefficients from logit regression are reported. Robust standard errors are in parenthesis. Each regression includes 4-digit SIC industry controls. Due to confidentiality, some variables are combined (collapsed together). A one period lag productivity measurement is used here. The omitted categories are as follows: investment age 9+, the medium plant age category, the smallest size category, SIC $=2017$ (Poultry and Egg Processing). ***, **, and * represent 1,5 , and $10 \%$ significance, respectively. 
Table 12. Logit Results: The Probability of Having an Investment Spike in the Dairy Products Industry.

\begin{tabular}{|c|c|c|c|c|}
\hline & $\begin{array}{l}\text { Medium Quz } \\
\text { (1) }\end{array}$ & nts & $\begin{array}{l}\text { All Plants Together } \\
\text { (2) }\end{array}$ & \\
\hline & Coefficients & Marginal Effect & Coefficients & Marginal Effect \\
\hline \multicolumn{5}{|l|}{ Investment Age } \\
\hline \multirow[t]{2}{*}{0 years old } & $2.68687^{* * * *}$ & $0.43916^{* * *}$ & $2.53666 * * *$ & $0.44955^{* * *}$ \\
\hline & $(0.29713)$ & $(0.06336)$ & (0.19385) & $(0.04188)$ \\
\hline \multirow[t]{2}{*}{1 year old } & $1.58129^{* * *}$ & $0.19529 * * *$ & $1.27597 * * *$ & $0.17085^{* * *}$ \\
\hline & $(0.30938)$ & $(0.05211)$ & $(0.20715)$ & $(0.03563)$ \\
\hline \multirow[t]{2}{*}{2 years old } & $1.24220^{* * *}$ & $0.13909 * * *$ & $1.32163^{* * *}$ & $0.17952^{* * *}$ \\
\hline & $(0.32734)$ & $(0.04858)$ & $(0.20688)$ & $(0.03629)$ \\
\hline \multirow[t]{2}{*}{3 years old } & $0.95810^{* * *}$ & $0.09916^{* *}$ & $0.73096 * * *$ & $0.08486 * *$ \\
\hline & $(0.36037)$ & $(0.04787)$ & $(0.24326)$ & $(0.03412)$ \\
\hline \multirow[t]{2}{*}{$4 \& 5$ years old } & $0.70743 * *$ & $0.06532^{*}$ & $0.72883^{* * *}$ & $0.08194^{* * *}$ \\
\hline & $(0.33725)$ & $(0.03698)$ & $(0.21367)$ & $(0.02821)$ \\
\hline \multirow[t]{2}{*}{6 years old and more } & 0.14789 & 0.01155 & $0.42498^{*}$ & $0.04378^{*}$ \\
\hline & $(0.37571)$ & $(0.03054)$ & $(0.22353)$ & $(0.02546)$ \\
\hline \multicolumn{5}{|l|}{ Plant Age } \\
\hline \multirow[t]{2}{*}{ Age 0} & -0.02013 & -0.00149 & 0.03743 & 0.00347 \\
\hline & $(0.23445)$ & $(0.01736)$ & $(0.14773)$ & $(0.01385)$ \\
\hline \multirow[t]{2}{*}{ Age1 } & -0.15293 & -0.01088 & -0.05693 & -0.00514 \\
\hline & $(0.28948)$ & $(0.01955)$ & $(0.18695)$ & $(0.01657)$ \\
\hline \multicolumn{5}{|l|}{ Plant Size } \\
\hline \multirow[t]{2}{*}{ Medium } & 0.26202 & 0.02084 & 0.02402 & 0.00222 \\
\hline & $(0.24333)$ & $(0.0205)$ & $(0.15463)$ & $(0.01435)$ \\
\hline \multirow[t]{2}{*}{ Medium-Large } & 0.12938 & 0.00994 & -0.00861 & -0.00079 \\
\hline & $(0.23979)$ & $(0.0189)$ & $(0.15605)$ & $(0.01429)$ \\
\hline \multirow[t]{2}{*}{ Largest } & 0.19048 & 0.01483 & -0.12021 & -0.01079 \\
\hline & $(0.24495)$ & $(0.01982)$ & $(0.16012)$ & $(0.01403)$ \\
\hline \multirow[t]{2}{*}{ Productivity } & $-1.45948^{* * *}$ & $-0.10926 * * *$ & $-0.61373^{*}$ & $-0.05641 *$ \\
\hline & $(0.54372)$ & $(0.04056)$ & $(0.31883)$ & $(0.02925)$ \\
\hline $\mathrm{N}$ & 1723 & & 3424 & \\
\hline
\end{tabular}

Note: Coefficients from the logit regression are reported. Robust standard errors are in parenthesis. Each regression includes 4-digit SIC industry controls. Due to confidentiality, some variables are combined (collapsed together). A one period lag productivity measurement is used here. The omitted categories are as follows: investment age $9+$, the oldest plant age category, the smallest size category, SIC $=2021$ (Creamery Butter). ***, **, and * represent 1,5 , and $10 \%$ significance, respectively. 
Table 13. Logit Results: The Probability of Having an Investment Spike in the Food Manufacturing Industry.

\begin{tabular}{|c|c|c|c|c|c|c|c|c|}
\hline & \multicolumn{2}{|c|}{$\begin{array}{l}\text { Smallest Quartile Ranked Plants } \\
\text { (1) }\end{array}$} & \multicolumn{2}{|c|}{$\begin{array}{l}\text { Medium Quartile Ranked Plants } \\
\text { (2) }\end{array}$} & \multicolumn{2}{|c|}{$\begin{array}{l}\text { Highest Quartile Ranked Plants } \\
\text { (3) }\end{array}$} & \multicolumn{2}{|c|}{$\begin{array}{l}\text { All Plants Together } \\
\text { (4) }\end{array}$} \\
\hline & Coefficients & Marginal Effect & Coefficients & Marginal Effect & Coefficients & $\begin{array}{l}\text { Marginal } \\
\text { Effect }\end{array}$ & Coefficients & Marginal Effect \\
\hline \multicolumn{9}{|l|}{ Investment Age } \\
\hline 0 years old & $\begin{array}{l}1.21209^{* * *} \\
(0.28737)\end{array}$ & $\begin{array}{l}0.12131 * * * \\
(0.04254)\end{array}$ & $\begin{array}{l}1.88303^{* * *} \\
(0.13308)\end{array}$ & $\begin{array}{l}0.22141^{* * *} \\
(0.02438)\end{array}$ & $\begin{array}{l}1.66235^{* * *} \\
(0.22984)\end{array}$ & $\begin{array}{l}0.19355^{* * *} \\
(0.04198)\end{array}$ & $\begin{array}{l}1.45631^{* * * *} \\
(0.12522)\end{array}$ & $\begin{array}{l}0.15332 * * * \\
(0.02026)\end{array}$ \\
\hline 1 year old & $\begin{array}{l}0.50097 * * \\
(0.20247)\end{array}$ & $\begin{array}{l}0.03645^{* *} \\
(0.01751)\end{array}$ & $\begin{array}{l}1.34515^{* * *} \\
(0.11824)\end{array}$ & $\begin{array}{l}0.12275^{* * *} \\
(0.01513)\end{array}$ & $\begin{array}{l}0.60850^{* * *} \\
(0.18006)\end{array}$ & $\begin{array}{l}0.04487^{* * *} \\
(0.01607)\end{array}$ & $\begin{array}{l}0.86477 * * * \\
(0.08919)\end{array}$ & $\begin{array}{l}0.06827 * * * \\
(0.00912)\end{array}$ \\
\hline 2 year old & $\begin{array}{l}0.69181^{* * *} \\
(0.16889)\end{array}$ & $\begin{array}{l}0.05337 * * * \\
(0.01618)\end{array}$ & $\begin{array}{l}1.19689 * * * \\
(0.12074)\end{array}$ & $\begin{array}{l}0.10330 * * * \\
(0.01424)\end{array}$ & $\begin{array}{l}0.76718^{* * *} \\
(0.16740)\end{array}$ & $\begin{array}{l}0.05948^{* * *} \\
(0.01626)\end{array}$ & $\begin{array}{l}0.98203 * * * \\
(0.08226)\end{array}$ & $\begin{array}{l}0.07990^{* * *} \\
(0.00883)\end{array}$ \\
\hline 3 year old & $\begin{array}{l}0.63429^{* * *} \\
(0.17574)\end{array}$ & $\begin{array}{l}0.04799^{* * *} \\
(0.01625)\end{array}$ & $\begin{array}{l}1.02103^{* * *} \\
(0.13101)\end{array}$ & $\begin{array}{l}0.08374 * * * \\
(0.01437)\end{array}$ & $\begin{array}{l}0.38414 * * \\
(0.19496)\end{array}$ & $\begin{array}{l}0.02614^{*} \\
(0.01508)\end{array}$ & $\begin{array}{l}0.76293 * * * \\
(0.09115)\end{array}$ & $\begin{array}{l}0.05791^{* * *} \\
(0.00873)\end{array}$ \\
\hline 4 year old & $\begin{array}{l}0.42333^{* *} \\
(0.18377)\end{array}$ & $\begin{array}{l}0.02962^{* *} \\
(0.01478)\end{array}$ & $\begin{array}{l}0.73259 * * * \\
(0.15104)\end{array}$ & $\begin{array}{l}0.05451 * * * \\
(0.01422)\end{array}$ & $\begin{array}{l}0.62932^{* * *} \\
(0.19081)\end{array}$ & $\begin{array}{l}0.04715^{* * *} \\
(0.01754)\end{array}$ & $\begin{array}{l}0.63707 * * * \\
(0.09892)\end{array}$ & $\begin{array}{l}0.04643^{* * *} \\
(0.00886)\end{array}$ \\
\hline 5 year old & $\begin{array}{l}0.18100 \\
(0.21819)\end{array}$ & $\begin{array}{l}0.01163 \\
(0.01497)\end{array}$ & $\begin{array}{l}0.43391 * * \\
(0.17262)\end{array}$ & $\begin{array}{l}0.02882^{* *} \\
(0.01334)\end{array}$ & $\begin{array}{l}0.32746 \\
(0.21063)\end{array}$ & $\begin{array}{l}0.02189 \\
(0.01577)\end{array}$ & $\begin{array}{l}0.32573 * * * \\
(0.11323)\end{array}$ & $\begin{array}{l}0.02114 * * * \\
(0.00824)\end{array}$ \\
\hline 6 year old & $\begin{array}{l}0.03819 \\
(0.23786)\end{array}$ & $\begin{array}{l}0.00233 \\
(0.0147)\end{array}$ & $\begin{array}{l}0.26186 \\
(0.18902)\end{array}$ & $\begin{array}{l}0.01628 \\
(0.01294)\end{array}$ & $\begin{array}{l}-0.13279 \\
(0.26504)\end{array}$ & $\begin{array}{l}-0.00747 \\
(0.01417)\end{array}$ & $\begin{array}{l}0.09466 \\
(0.12856)\end{array}$ & $\begin{array}{l}0.00563 \\
(0.00792)\end{array}$ \\
\hline 7 year old & $\begin{array}{l}-0.13615 \\
(0.25674)\end{array}$ & $\begin{array}{l}-0.00776 \\
(0.01389)\end{array}$ & $\begin{array}{l}0.08337 \\
(0.21424)\end{array}$ & $\begin{array}{l}0.00484 \\
(0.01284)\end{array}$ & $\begin{array}{l}-0.06427 \\
(0.26440)\end{array}$ & $\begin{array}{l}-0.00371 \\
(0.01489)\end{array}$ & $\begin{array}{l}-0.01473 \\
(0.13916)\end{array}$ & $\begin{array}{l}-0.00084 \\
(0.00789)\end{array}$ \\
\hline 8 year old & $\begin{array}{l}-0.07089 \\
(0.26261)\end{array}$ & $\begin{array}{l}-0.00414 \\
(0.01493)\end{array}$ & $\begin{array}{l}0.10289 \\
(0.21434)\end{array}$ & $\begin{array}{l}0.00602 \\
(0.01304)\end{array}$ & $\begin{array}{l}0.09620 \\
(0.26563)\end{array}$ & $\begin{array}{l}0.00591 \\
(0.01693)\end{array}$ & $\begin{array}{l}0.07482 \\
(0.14016)\end{array}$ & $\begin{array}{l}0.00442 \\
(0.00852)\end{array}$ \\
\hline \multicolumn{9}{|l|}{ Plant Age } \\
\hline Age 0 & $\begin{array}{l}0.14137 \\
(0.14863)\end{array}$ & $\begin{array}{l}0.00888 \\
(0.00976)\end{array}$ & $\begin{array}{l}-0.01956 \\
(0.10334)\end{array}$ & $\begin{array}{l}-0.00109 \\
(0.00573)\end{array}$ & $\begin{array}{l}0.27838^{*} \\
(0.14433)\end{array}$ & $\begin{array}{c}0.01799 * \\
(0.01014)\end{array}$ & $\begin{array}{l}0.13044 * \\
(0.07393)\end{array}$ & $\begin{array}{l}0.00779 * \\
(0.0046)\end{array}$ \\
\hline Age1 & $\begin{array}{l}0.00269 \\
(0.17915)\end{array}$ & $\begin{array}{l}0.00016 \\
(0.01078)\end{array}$ & $\begin{array}{l}0.03991 \\
(0.12085)\end{array}$ & $\begin{array}{l}0.00227 \\
(0.00698)\end{array}$ & $\begin{array}{l}0.33462^{* *} \\
(0.16833)\end{array}$ & $\begin{array}{l}0.02233^{*} \\
(0.01256)\end{array}$ & $\begin{array}{l}0.13704 \\
(0.08622)\end{array}$ & $\begin{array}{l}0.00825 \\
(0.00545)\end{array}$ \\
\hline \multicolumn{9}{|l|}{ Plant Size } \\
\hline Medium & $\begin{array}{l}-0.18471 \\
(0.17236)\end{array}$ & $\begin{array}{l}-0.01069 \\
(0.00963)\end{array}$ & $\begin{array}{l}-0.29960 * * \\
(0.12381)\end{array}$ & $\begin{array}{l}-0.01573^{* * *} \\
(0.00607)\end{array}$ & $\begin{array}{l}0.09464 \\
(0.16423)\end{array}$ & $\begin{array}{l}0.00571 \\
(0.01011)\end{array}$ & $\begin{array}{l}-0.15380^{*} \\
(0.08644)\end{array}$ & $\begin{array}{l}-0.00853^{*} \\
(0.00464)\end{array}$ \\
\hline Medium-Large & $\begin{array}{l}-0.17156 \\
(0.18932)\end{array}$ & $\begin{array}{l}-0.00993 \\
(0.01057)\end{array}$ & $\begin{array}{l}-0.09006 \\
(0.13309)\end{array}$ & $\begin{array}{l}-0.00496 \\
(0.00718)\end{array}$ & $\begin{array}{l}0.04702 \\
(0.18629)\end{array}$ & $\begin{array}{l}0.00281 \\
(0.01125)\end{array}$ & $\begin{array}{l}-0.13312 \\
(0.09537)\end{array}$ & $\begin{array}{l}-0.00741 \\
(0.00516)\end{array}$ \\
\hline Largest & $\begin{array}{l}-0.29188 \\
(0.20362)\end{array}$ & $\begin{array}{l}-0.01640 \\
(0.0107)\end{array}$ & $\begin{array}{l}-0.43950^{* * * *} \\
(0.14828)\end{array}$ & $\begin{array}{l}-0.02264 * * * \\
(0.00701)\end{array}$ & $\begin{array}{l}-0.06010 \\
(0.20797)\end{array}$ & $\begin{array}{l}-0.00351 \\
(0.01198)\end{array}$ & $\begin{array}{l}-0.28621^{* * *} \\
0.10504\end{array}$ & $\begin{array}{l}-0.01544^{* * *} \\
(0.00533)\end{array}$ \\
\hline \multirow[t]{2}{*}{ Productivity } & $\begin{array}{l}-1.69693^{* *} \\
(0.71877)\end{array}$ & $\begin{array}{l}-0.10189^{* *} \\
(0.04302)\end{array}$ & $\begin{array}{l}-0.66817 * * \\
(0.30300)\end{array}$ & $\begin{array}{l}-0.03751 * * \\
(0.01701)\end{array}$ & $\begin{array}{l}-1.32799^{* * *} \\
(0.49753)\end{array}$ & $\begin{array}{l}-0.07856^{* * *} \\
(0.02931)\end{array}$ & $\begin{array}{l}-0.55028^{* *} \\
(0.27791)\end{array}$ & $\begin{array}{l}-0.03155^{* *} \\
(0.01592)\end{array}$ \\
\hline & 5728 & & 12609 & & 5989 & & 24372 & \\
\hline
\end{tabular}

Note: Coefficients from the logit regression are reported. Robust standard errors are in parenthesis. Each regression includes 4-digit SIC industry controls. For the productivity measure, a four year moving average was used for the smallest, a two year moving average for the medium, a three year moving average for the highest and all food plants. The omitted categories are as follows: investment age 9+, the oldest plant age category, the smallest size category, SIC=2011 (Meat Packing). $* * *$, $* *$, and $*$ represent 1,5 , and $10 \%$ significance, respectively. 


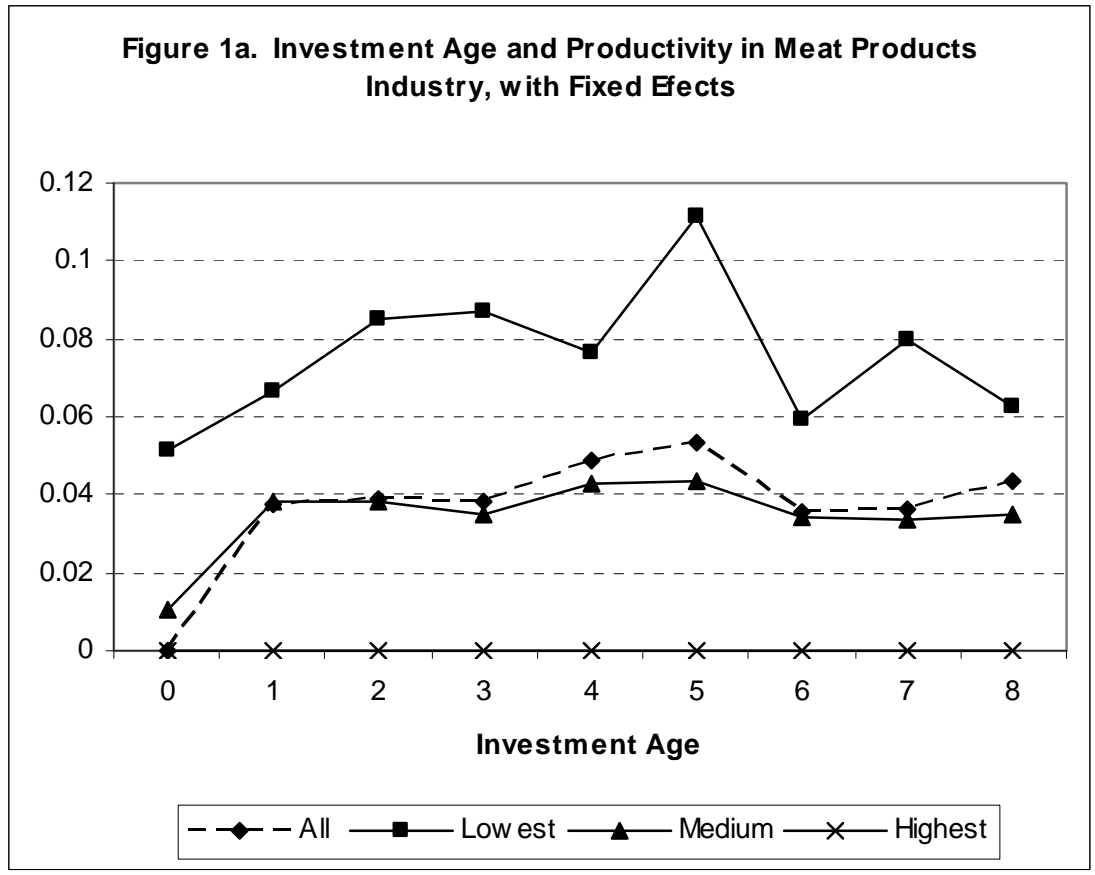




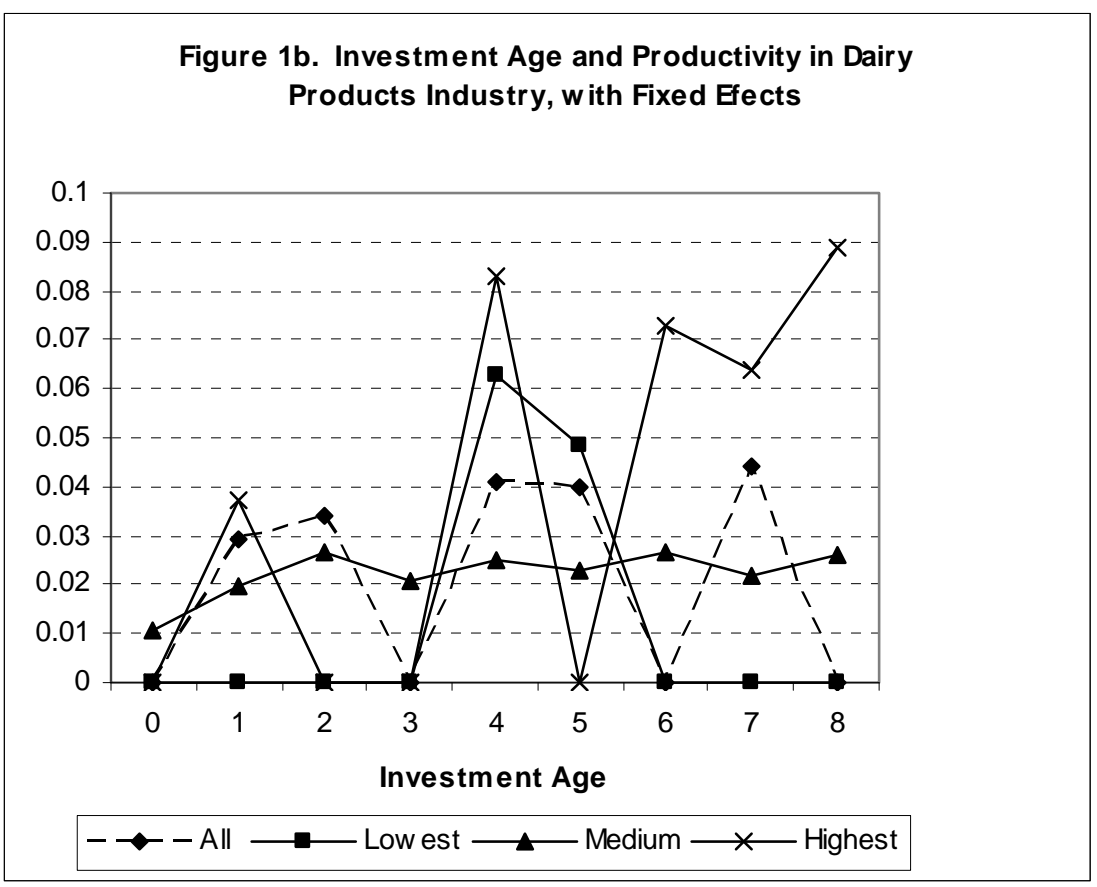




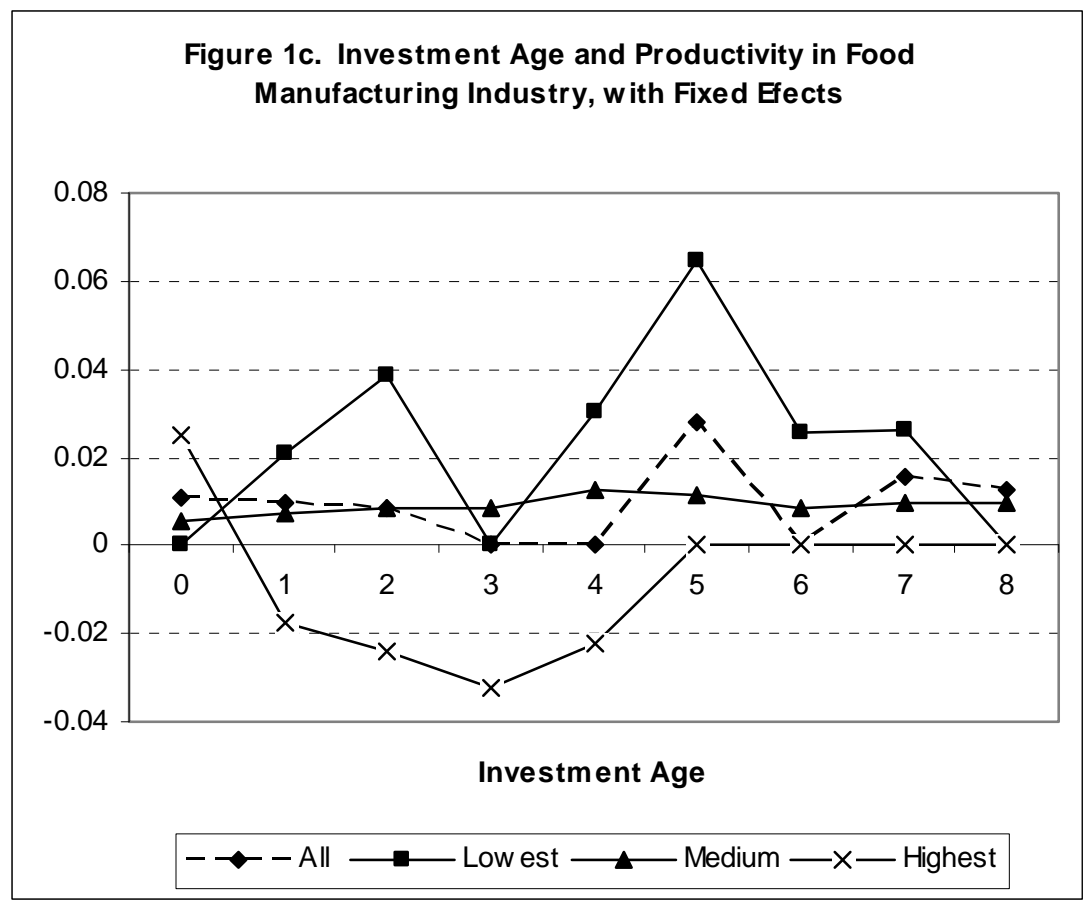




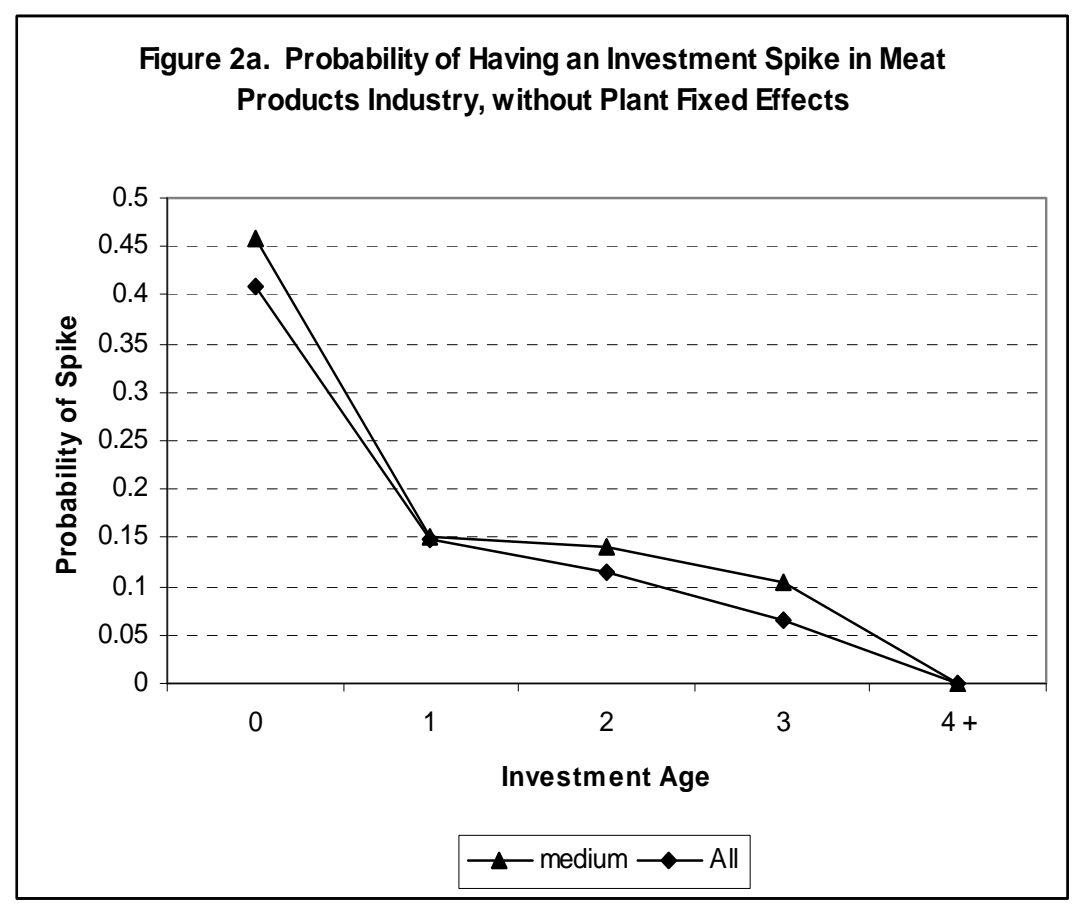




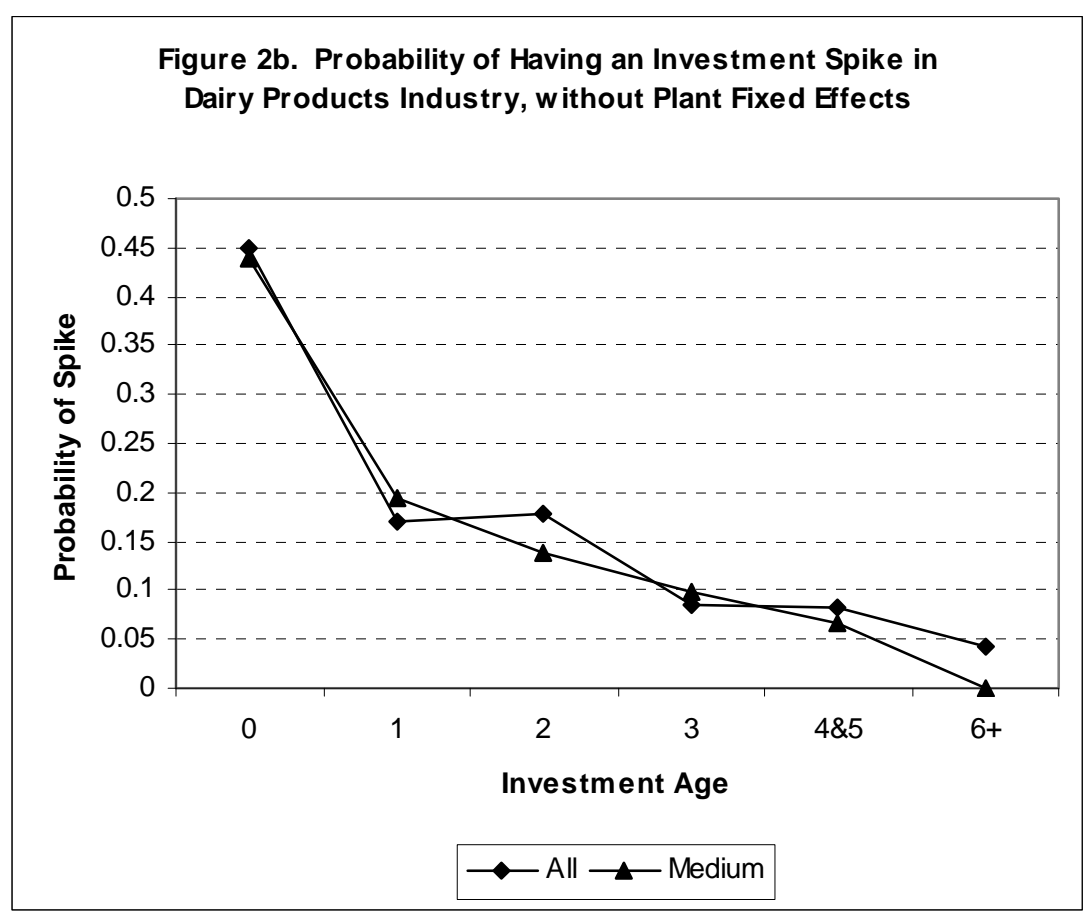




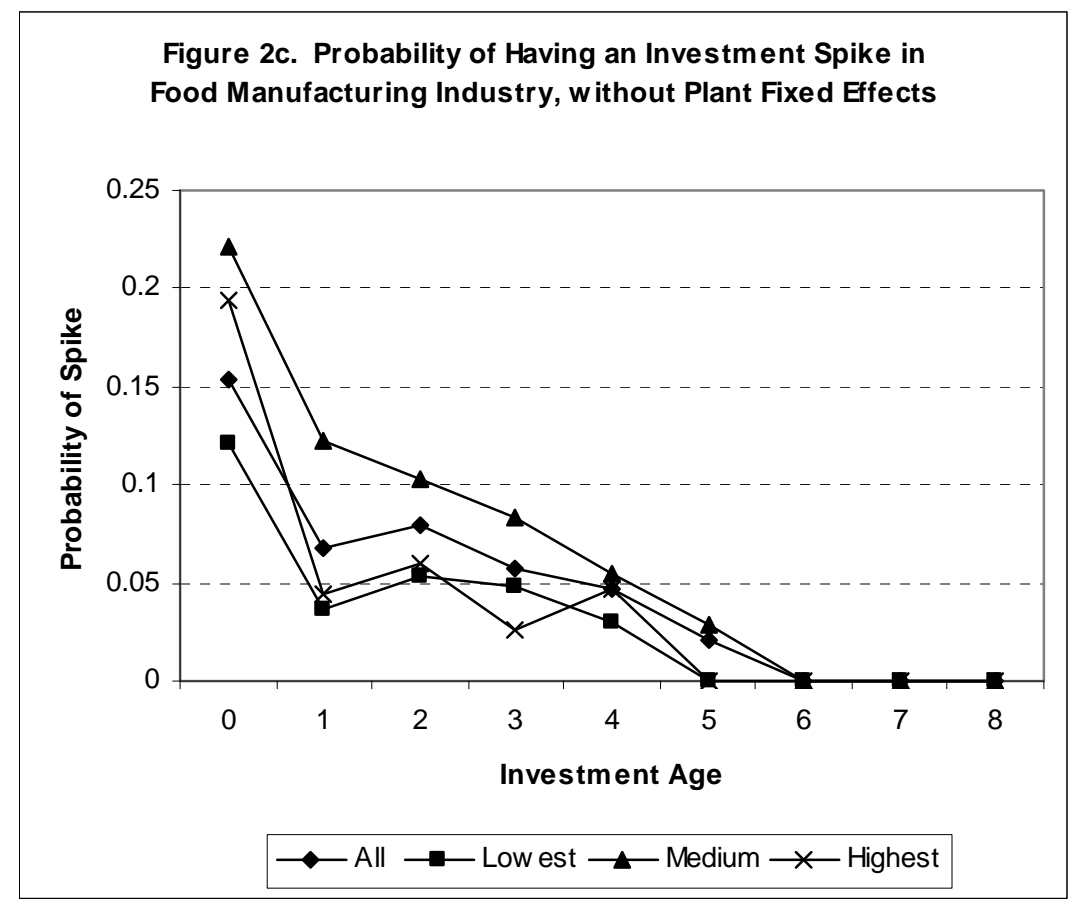




\section{ENDNOTES}

${ }^{1}$ Investment spikes are defined typically as an absolute spike when the investment rate exceed 20\% and as a relative spike when the investment rate exceeds the median investment rate by a factor which is typically set between 1.5 and 3.75 [see Power (1998), Cooper, Haltiwanger and Power (1999)] of each plant.

${ }^{2}$ The CM, which is conducted every five years, samples every U.S. manufacturing plant. The ASM continuously samples plants with more than 250 employees. Continuous data exist for large plants and for small plants that are selected to be part of the ASM panel. Small plants have missing information for all years except CM, and ASM panel years if the plant is selected to be part of an ASM; therefore, comprehensive time series information on small plants is not available.

${ }^{3}$ Use of balanced panel precludes us to model the entry/exit process which may create a selection bias. However, our decision to use balanced panel based on the difficult measurement issues for capital variable in the unbalanced panel setting. Other studies which face similar capital measurement difficulties use balanced panel (Caballero, Engel, and Haltiwanger (1995), Cooper, Haltiwanger and Power (1999), Cooper and Haltiwanger (2006).

${ }^{4}$ We also tried absolute spike definition. Our results were not strikingly different across definitions.

${ }^{5}$ Power (1994) defines spikes as abnormally high investment episodes relative to the typical investment rate experienced within a plant and considers various hurdles over the median investment rates (such as 1.75, 2.5, 3.5 times of median investment rate) to reflect abnormally high investment episodes. An excellent extensive investigation of these alternative specifications of investment spikes and their comparisons can be found in this paper.

${ }^{6}$ Confidentiality restrictions preclude us to report information for plants which present greater spike episodes than the ones that are reported in this table. 
${ }^{7}$ The variable construction is described in more detail in the Appendix.

${ }^{8}$ We tried material and energy inputs as possible proxy variables in specifying the Leveinsohn-Petrin estimation. Based on the characteristics of the data (less nonzero values in energy) and the results from least squares/Leveinsohn-Petrin coefficients on variable inputs, we have chosen energy input as a proxy.

${ }^{9}$ To see if the least squares coefficient on capital will be biased upward or downward depends on the degree of correlation among inputs and the productivity shocks (Levinsohn and Petrin (2003)). They suggest that if capital also respond to the productivity shock, we also see upwardly biased capital coefficient, however, there might be situation as capital is not correlated with the period's transmitted shock (but variable inputs are) or capital is much less weakly correlated with the productivity shock than the variable inputs are, then, the least squares estimate on capital is likely to be biased downward (Levinsohn and Petrin (2003)). Our results show that, in meat and dairy industries the least squares estimate is less than the Levinsohn-Petrin estimate which indicates the least squares coefficient on capital is biased downward and in all food industry the least squares estimate is higher than the LP estimate which indicates the least squares coefficient on capital is biased upward.

${ }^{10}$ Our industry dummies are at the 4-digit SIC level, which shows a 4-digit output composition. We have five such industries for Meat and Dairy products, and 51 for the entire food industry.

${ }^{11}$ See Appendix for variable construction.

${ }^{12}$ In plant level estimation, if there is an unobserved heterogeneity across plants, the estimated coefficient using least squares without controlling for the fixed effects yields biased results. Therefore, we run a least squares regression with plant-level fixed effects to eliminate this potential bias. 
${ }^{13}$ When we draw our figures, we use 0 for insignificant coefficients to see trends in how investment age affects productivity.

${ }^{14}$ Investment age coefficients illustrate the relationship between productivity growth and investment age for the average plant relative to the omitted investment age group $9+$.

${ }^{15}$ These two sub-industries differ in two important aspects. The first is by the role of government pricing regulation. Where meat products are free from direct government pricing influence, the dairy products sector has the price of raw material (milk) regulated and regulation influencing the pricing of fluid milk prices in some regions through marketing orders. The second aspect is in terms of technology differences between the two sub-industries. The meat products sub-industry prepares a range of products that flow off a common line of production as products are further processed (e.g., cuts of meat processed into lunch meats, sausages). Milk products tend to involve a wide range of different technologies (e.g., cheese-making, yogurt, ice cream) that have specialized equipment with milk entering in these specific sub-product processes at a less processes state in a fairly unprocessed form.)

${ }^{16}$ The TFP level used is the value generated accounting for the productivity shocks.

${ }^{17}$ The patterns from these figures show the variation in the probability of investment spikes with respect to investment age across plants. The coefficients here are relative to the omitted investment age group $9+$.

${ }^{18}$ Due to the confidentially reasons, some dummy variables were collapsed into broader categories. Further, Census disclosures guidelines prevent revealing the estimates of the meat product highest and lowest ranked plants.

${ }^{19}$ We still find a decreasing hazard function even though we control for unobserved plant fixed effects in the meat industry. 
${ }^{20}$ The obvious drawback of the value added approach is the assumption that material inputs are separable from other inputs, and cannot be a source of productivity growth. Most of the food industries are characterized as being materials intensive. The ratio of material cost to value of shipments in the U.S. food manufacturing sector exceeds $60 \%$. In some food-manufacturing industries such as meat products and the fats and oils industries, this ratio is even reaching $80 \%$. Therefore, considering materials as a component of the production function specification impacts the productivity measurement results.

${ }^{21}$ This method is used by researchers who use the Census Bureau's LRD to generate the real capital stock series such as Cooper, Haltiwanger and Power (1999), and Dwyer (1996). 